\title{
Superhydrophobic polycarbosilane membranes for purification of solar hydrogen
}

\author{
Miwako Kubo ${ }^{a}$, Kohei Okibayashi ${ }^{a}$, Misako Kojima ${ }^{a}$, Ryota Mano ${ }^{a}$, Yusuke Daiko ${ }^{a}$, \\ Sawao Honda a, Samuel Bernard b, Yuji Iwamoto a,* \\ ${ }^{a}$ Department of Life Science and Applied Chemistry, Graduate School of Engineering, Nagoya Institute of Technology, Gokiso-cho, Showa-ku, Nagoya 466-8555, Japan \\ ${ }^{\mathrm{b}}$ Univ. Limoges, CNRS, IRCER, UMR 7315, F-87000 Limoges, France
}

\section{A R T I C LE IN F O}

\section{Keywords:}

Polycarbosilanes (PCSs)

Hydrophobic SiCH organic-inorganic hybrid

Hydrogen-selective membrane

Preferential hydrogen permeation

Permeate $\mathrm{H}_{2} \mathrm{O}$-induced plugging

\begin{abstract}
A B S T R A C T
Superhydrophobic membranes composed of an organic-inorganic hybrid polymer, namely polycarbosilane (PCS) with $\mathrm{Mw}$ of $4-8.9 \times 10^{3}$, were formed on a mesoporous $\gamma-\mathrm{Al}_{2} \mathrm{O}_{3}$-modified $\alpha-\mathrm{Al}_{2} \mathrm{O}_{3}$ porous support. Under dry condition at $50{ }^{\circ} \mathrm{C}$, the supported PCS membranes exhibited $\mathrm{H}_{2}$ permeance of $1.1-1.6 \times 10^{-6} \mathrm{~mol} \cdot \mathrm{m}^{-2} \cdot \mathrm{s}^{-1} \cdot \mathrm{Pa}^{-1}$ and $\mathrm{H}_{2} / \mathrm{N}_{2}$ selectivity of 9.7-12.6 together with unique $\mathrm{H}_{2} / \mathrm{He}$ selectivity of 1.4-1.6. Even under saturated humidity at $50{ }^{\circ} \mathrm{C}, \mathrm{H}_{2}$ permeance remained at $7.7 \times 10^{-8} \mathrm{~mol}^{-1} \mathrm{~m}^{-2} \mathrm{~s}^{-1} \mathrm{~Pa}^{-1}$ with improved $\mathrm{H}_{2} / \mathrm{N}_{2}$ selectivity of 26. Moreover, when the measurements were performed using a $\mathrm{H}_{2}-\mathrm{N}_{2}$ (2:1) mixed feed gas as a simulated syngas produced by novel solar hydrogen production systems, the $\mathrm{H}_{2}$ permeance almost unchanged, while the $\mathrm{N}_{2}$ permeance was below the limit of detection. These results revealed a great potential of PCSs to develop novel $\mathrm{H}_{2-}$ selective membranes for purifying solar hydrogen under high-humidity conditions around $50{ }^{\circ} \mathrm{C}$. Further study on the gas permeation behaviors of $\mathrm{He}, \mathrm{H}_{2}$ and $\mathrm{N}_{2}$ suggested that the enhanced $\mathrm{H}_{2} / \mathrm{N}_{2}$ selectivity under the highhumidity conditions could be explained by the synergistic effect of preferential $\mathrm{H}_{2}$ permeation through the dense PCS network governed by the solid state diffusion mechanism and blockage of $\mathrm{N}_{2}$ permeation through micropore channels within the PCS network by the permeate $\mathrm{H}_{2} \mathrm{O}$-induced plugging at around the hetero interface between the superhydrophobic PCS and highly hydrophilic $\gamma-\mathrm{Al}_{2} \mathrm{O}_{3}$.
\end{abstract}

\section{Introduction}

Because of its high potential to replace the current hydrogen production by the steam reforming of naphtha and methane, photoelectrochemical (PEC) water-splitting [1-3] has received much attention as an environmental-friendly hydrogen production method. However, due to its co-production of gaseous hydrogen $\left(\mathrm{H}_{2}\right)$ and oxygen $\left(\mathrm{O}_{2}\right)$ which explosively react in a wide range (4-95\%) of $\mathrm{H}_{2}$ concentration [4], $\mathrm{H}_{2}$ gas must be immediately separated from the syngas under the high-humidity conditions at low temperatures around $50{ }^{\circ} \mathrm{C}$ [5].

Membrane separation is attractive as one of the low-cost $\mathrm{H}_{2}$ gas purification technologies. However, under the required $\mathrm{H}_{2}$ gas separation conditions, there are technical issues such as water-induced swelling for polymer membranes and lower $\mathrm{H}_{2}$ permeance for metal [6], polymer [7] and supported liquid membranes [8]. Microporous amorphous silica $\left(\mathrm{SiO}_{2}\right)$ membranes exhibit a higher $\mathrm{H}_{2}$-permselectivity [9]. However, under such high-humidity conditions, serious performance degradation occurs $[5,10,11]$.

On the other hand, organic-inorganic hybrid materials have been designed and synthesized to develop novel functional materials over the last decade $[12,13]$. These hybrids are often synthesized through the solgel route using organo-substituted silicon alkoxides to afford Class II hybrids according to the classification given by Sanchez [14], where the organic and inorganic components are linked together by strong chemical bonds. In particular, the introduction of organic groups into an inorganic network can provide various tunable properties such as flexibility, solublity, hydrophobicity and negligible swelling in aqueous or organic solvents [13-15].

Polycarbosilanes (PCSs) expressed by a general formula of $[-\mathrm{Si}$ $\left.\left(\mathrm{CH}_{3}\right)(\mathrm{R})-\mathrm{CH}_{2}{ }^{-}\right]_{\mathrm{n}}\left(\mathrm{R} \mathrm{EH}_{3}, \mathrm{H}\right)$ are well known polymer precursors for synthesizing silicon carbide ( $\mathrm{SiC}$ )-based ceramics at $\mathrm{T}>1000{ }^{\circ} \mathrm{C}$ $[16,17]$, and they have been successfully converted to thermally stable inorganic components in the form of long fibers, filters and porous membranes [16-19].

\footnotetext{
* Corresponding author.

E-mail address: iwamoto.yuji@nitech.ac.jp (Y. Iwamoto).
} 
However, PCSs are also appropriate as a Class II organic-inorganic hybrid: The polymer backbone composed of covalent silicon-carbon (Si-C) bond endows high flexibility, thermal and chemical stabilities of PCSs $[20,21]$, while the methyl $\left(\mathrm{CH}_{3}\right)$ groups attached to $\mathrm{Si}$ atoms provide stability toward amibient moisture of PCSs, which allowsPCSs to be applied as an active binder for fabricating polycrystalline SiC ceramics through the conventional powder metallurgy route [22]. More recently, PCS was found to be a useful modifier to convert hydrophilic mesoporous membrane surface into hydrophobic one [23].

The present study is firstly dedicated to the characterization of the hydrophobicity of supported PCS membranes in terms of stable gas permeations and unique preferential $\mathrm{H}_{2}$ permeation under high humidity conditions at low-temperatures around $50{ }^{\circ} \mathrm{C}$. By using high molecular weight PCSs having melting point above $200{ }^{\circ} \mathrm{C}$, we showed that a superhydrophobic PCS membrane could be deposited on a mesoporous $\gamma-\mathrm{Al}_{2} \mathrm{O}_{3}$-modified macroporous $\alpha-\mathrm{Al}_{2} \mathrm{O}_{3}$ tubular support. Then, gas permeation properties of the supported PCS membrane were characterized by measuring single gas permeances of helium $(\mathrm{He})$, hydrogen $\left(\mathrm{H}_{2}\right)$ and nitrogen $\left(\mathrm{N}_{2}\right)$ under dry condition at $25-80{ }^{\circ} \mathrm{C}$. Finally, the $\mathrm{H}_{2}-$ permselectivity was evaluated under water vapor partial pressures raging from 0.1 to 1 at $50{ }^{\circ} \mathrm{C}$ and compared with those of a conventional sol gel-derived $\mathrm{SiO}_{2}$ membrane. Possible mechanisms for gas permeations through the supported PCS membranes were discussed based on the gas permeation behaviors with unique $\mathrm{H}_{2} / \mathrm{He}$ selectivity under dry condition up to $200{ }^{\circ} \mathrm{C}$, improved $\mathrm{H}_{2} / \mathrm{N}_{2}$ selectivity under the highhumidity conditions at $50{ }^{\circ} \mathrm{C}$ and significantly high hydrophobicity of the PCSs characterized by measuring water vapor adsorption-desorption isotherms at $25{ }^{\circ} \mathrm{C}$. Moreover, excellent $\mathrm{H}_{2}$-selectivity under saturated humidity at $50{ }^{\circ} \mathrm{C}$ of the supported PCS membrane was demostrated by using a $\mathrm{H}_{2}-\mathrm{N}_{2}$ (2:1) mixed feed gas as a simulated syngas produced by the novel solar hydrogen production via the PEC water-splitting reaction.

\section{Experimental procedures}

\subsection{Synthesis of PCS membranes}

In this study, commercially available PCSs (Type A, UH and UUH, Artkagaku Co., Ltd., Ibaragi, Japan) were used as received. Table 1 listed melting point (m.p.) and chemical composition of the PCSs provided by the supplier [24]. As shown in Table 1 and Fig. S1 in SEI, gel permeation chromatography (GPC) analysis at our laboratory revealed that the number average molecular weight $(\mathrm{Mn})$ and the mean molecular weight (Mw) of PCS(UUH) were apparently higher than those of $\mathrm{PCS}(\mathrm{UH})$, which suggested that the m.p. of PCS(UUH) could be above $350{ }^{\circ} \mathrm{C}$ and/ or no definite temperature as reported by the supplier [24].

A commercially available $\alpha-\mathrm{Al}_{2} \mathrm{O}_{3}$ tubular support $(6 \mathrm{~mm}$ outer diameter, $4 \mathrm{~mm}$ inner diameter and $60 \mathrm{~mm}$ length, total porosity of $40 \%$, Noritake Co., Ltd., Aichi, Japan) was used. This $\alpha-\mathrm{Al}_{2} \mathrm{O}_{3}$ tubular support consisted of a core with a mean pore diameter $\left(d_{c o r e}\right)$ of $700 \mathrm{~nm}$ and a rim with a $d_{\text {rim }}$ of $150 \mathrm{~nm}$.

A mesoporous $\gamma-\mathrm{Al}_{2} \mathrm{O}_{3}$ layer with a thickness of about $3.5 \mu \mathrm{m}$ was fabricated on the outer surface of the macroporous $\alpha-\mathrm{Al}_{2} \mathrm{O}_{3}$ tubular support by following reported procedures $[25,26]$.

Table 1

Properties of PCSs.

\begin{tabular}{|c|c|c|c|c|c|c|c|c|c|}
\hline \multirow[t]{2}{*}{$\begin{array}{l}\text { PCS } \\
\text { Type }\end{array}$} & \multirow[t]{2}{*}{$\mathrm{Mn} /-$} & \multirow[t]{2}{*}{$\mathrm{Mw} /-$} & \multirow[t]{2}{*}{$\begin{array}{l}\mathrm{Mw} / \\
\mathrm{Mn}\end{array}$} & \multirow[t]{2}{*}{$\begin{array}{l}\text { m. p./ } \\
{ }^{\circ} \mathrm{C}[24]\end{array}$} & \multicolumn{5}{|c|}{$\begin{array}{l}\text { Chemical composition/wt\% } \\
\text { [24] }\end{array}$} \\
\hline & & & & & Si & C & $\mathrm{H}$ & 0 & $\mathrm{~N}$ \\
\hline A & 1318 & 4042 & 3.07 & 230 & 50 & 40 & 8.1 & 0.5 & 0.7 \\
\hline $\mathrm{UH}$ & 1668 & 5920 & 3.55 & $350 *$ & 50 & 40 & 8.2 & 1.4 & 1.7 \\
\hline UUH & 4183 & 8933 & $2.14-\mathrm{n}$ & & d. & $\begin{array}{l}\text { n. } \\
\text { d. }\end{array}$ & $\begin{array}{l}\mathrm{n} . \\
\text { d. }\end{array}$ & $\begin{array}{l}\text { n. } \\
\text { d. }\end{array}$ & $\begin{array}{l}\mathrm{n} . \\
\mathrm{d} .\end{array}$ \\
\hline
\end{tabular}

\footnotetext{
${ }^{*}$ Partial melting.
}

For PCS membrane synthesis, 1 wt\% solution of as-received PCS/dry xylene (super dehydrated grade, $99.5 \%$ purity, Wako Pure Chemical Co., Ltd., Osaka, Japan) was prepared for each type shown in Table 1 . The PCS solution was dip-coated on the mesoporous $\gamma-\mathrm{Al}_{2} \mathrm{O}_{3}$ layer placed on the outer surface of the macroporous $\alpha-\mathrm{Al}_{2} \mathrm{O}_{3}$ tubular support according to the procedures established in our previous study [23]. Then, the solvent (xylene) was removed from the PCS-coated layer by heat treatment at $120{ }^{\circ} \mathrm{C}$ to afford a PCS membrane supported on the mesoporous $\gamma-\mathrm{Al}_{2} \mathrm{O}_{3}$ layer placed on the outer surface of the macroporous $\alpha-\mathrm{Al}_{2} \mathrm{O}_{3}$ tubular support (Hereafter, the supported PCS membrane was labeled as $\mathrm{PCS}(\mathrm{X})$, where $\mathrm{X}$ denoted type of PCS).

\subsection{Characterizations}

GPC measurement for as-received PCSs was performed on a Shodex GPC-104 system (Showa Denko K.K., Tokyo, Japan) equipped with two tandem columns (Shodex LF-404, Showa Denko K.K., Tokyo, Japan) calibrated against standard polystyrenes and with a Shodex RI-74S detector (Showa Denko K.K., Tokyo, Japan) using tetrahydrofuran (THF) as eluent with a flow rate of $1.0 \mathrm{~mL} \mathrm{~min}^{-1}$ at $40{ }^{\circ} \mathrm{C}$.

Water vapor adsorption-desorption isotherms of the powder samples were measured at $25^{\circ} \mathrm{C}$ (Model BELSORP-aqua 3, MicrotracBEL Corp., Osaka, Japan). The powder samples of the as-received PCSs were prepared by solvent removal from the $\mathrm{PCS}(\mathrm{X})$ coating solution described above at $50{ }^{\circ} \mathrm{C}$ under vacuum followed by heat treatment at $120 \mathrm{C}$ for 1 h. As a reference sample, the measurement was also performed on $\mathrm{SiO}_{2}$ powder prepared by drying $\mathrm{SiO}_{2}$ sol coating solution at $60{ }^{\circ} \mathrm{C}$ for $1 \mathrm{~h}$ followed by heat treatment at $600^{\circ} \mathrm{C}$ in air. The Si@sol coating solution was prepared as follows: A mixture of $8.93 \mathrm{~mL}$ of tetraethoxysilane (99\%, Kishida Chemical Co., Ltd., Osaka, Japan)and 8.86 mL of ethanol (99.5\%, Kishida Chemical Co., Ltd., Osaka, Japan) was stirred, then peptized with a nitric acid aqueous solution of $0.357 \mathrm{~g}$ of $\mathrm{HNO}_{3}$ (60.0-61.0\%, Kishida Chemical Co., Ltd., Osaka, Japan) and $4.465 \mathrm{~g}$ of distillated water for $15 \mathrm{~min}$. The peptized mixture was refluxed at $80{ }^{\circ} \mathrm{C}$ for $3 \mathrm{~h}$. After cooling down to room temperature, the reaction mixture was diluted with $110.57 \mathrm{~g}$ of ethanol to give a $\mathrm{SiO}_{2}$ sol coating solution for $\mathrm{SiO}_{2}$ membrane synthesis.

Cross-sectional structure of the PCS membrane supported on the mesoporous $\gamma-\mathrm{Al}_{2} \mathrm{O}_{3}$ layer was observed by a scanning electron microscope (SEM, Model JSM-6360LV, JEOL Ltd., Tokyo, Japan) and examined by the energy dispersive X-ray spectroscopic (EDS) analysis (Model JSM-6010LA mounted on SEM, JEOL Ltd., Tokyo, Japan).

Single gas permeances through the supported PCS membranes were measured by the volumetric method at constant pressure. Single gas permeances under dry condition at $25-80{ }^{\circ} \mathrm{C}$ were measured in order of a kinetic diameter for $\mathrm{He}(0.26 \mathrm{~nm}), \mathrm{H}_{2}(0.289 \mathrm{~nm})$ and $\mathrm{N}_{2}(0.364 \mathrm{~nm})$ [27]. As for the PCS(UH), the single gas permeances were measured at temperatures up to $200{ }^{\circ} \mathrm{C}$.

Under wet condition, single gas permeances through the $\operatorname{PCS}(\mathrm{A})$ were measured at the water partial vapor pressures $\left(p / p_{0}\left(H_{2} \mathrm{O}\right)\right)$ ranging from 0.1 to 1 at $50{ }^{\circ} \mathrm{C}$. As a reference, the same measurements were performed on a sol gel-derived $\mathrm{SiO}_{2}$ membrane fabricated as follows: The $\mathrm{SiO}_{2}$ sol coating solution described above was dip-coated on the outer surface of the mesoporous $\gamma$ - $\mathrm{Al}_{2} \mathrm{O}_{3}$-modified $\alpha-\mathrm{Al}_{2} \mathrm{O}_{3}$ macroporous tubular support under the same manner as mentioned for the supported PCS membrane synthesis, then dried at $60{ }^{\circ} \mathrm{C}$ and subsequently heat-treated at $600{ }^{\circ} \mathrm{C}$ for $1 \mathrm{~h}$. This dip coating-drying-heating process was repeated 5 times.

As for the PCS $(A)$, gas permeances were also measured using a mixed feed gas with a $2: 1 \mathrm{M}$ ratio of $\mathrm{H}_{2}$ and $\mathrm{N}_{2}$ as a simulated syngas produced by the solar hydrogen production via the PEC water-splitting reaction.

The details of the procedures and the equipment setup for the gas permeation measurements have been reported elsewhere [23]. Single gas permeance of gas- $i\left(Q_{\mathrm{i}}\right)$ was calculated using Eq. (1), 


$$
Q_{\mathrm{i}}=\frac{V_{\mathrm{i}}}{S\left(p_{1}-p_{2}\right)}
$$

where $V_{\mathrm{i}}\left[\mathrm{mol} \mathrm{s}^{-1}\right]$ is the experimentally measured permeate molar flow rate of gas-i; $S\left[\mathrm{~m}^{2}\right]$ is the membranearea; $p_{1}[\mathrm{~Pa}]$ is pressure of the feed side; $p_{2}[\mathrm{~Pa}]$ is pressure of the permeate side. The pressure difference, $\left(p_{1}\right.$ $-p_{2}$ ) in Eq. (1) was fixed as $100 \mathrm{kPa}$ in this study.

Permselectivity was defined as the ratio of single gas permeances measured for the two kind of gases, for instance, the $\mathrm{H}_{2} / \mathrm{N}_{2}$ electivity $\left(\alpha\left(\mathrm{H}_{2} / \mathrm{N}_{2}\right)\right)$ was evaluated as the ratio $Q_{\mathrm{H} 2} / Q_{\mathrm{N} 2}$.

When the gas permeances were evaluated using a $\mathrm{H}_{2}-\mathrm{N}_{2}(2: 1)$ mixed feed gas, the permeate gas composition was determined by using a gas chromatograph (GC, Model CP-4900 Micro-GC, Varian medical systems Inc., CA, USA) and Ar sweep gas ( $\left.50 \mathrm{~mL} \mathrm{~min}^{-1}\right)$. Each gas permeance of $Q_{\mathrm{H} 2}$ and $Q_{\mathrm{N} 2}$ was evaluated by using the analyzed composition and the measured permeate molar flow rate. The water vapor permeance was evaluated using a gas chromatograph for polar gas analysis (GC323, GL Sciences Inc., Tokyo, Japan) according to the published procedure [23].

\section{Results and discussion}

\subsection{Hydrophobicity of as-received PCSs}

A significantly high hydrophobicity of as-received PCSs was characterized by measuring water vapor adsorption-desorption isotherms at $25{ }^{\circ} \mathrm{C}$ of powder samples (Fig. 1(a)). Compared with the mesoporous $\mathrm{\gamma}-\mathrm{Al}_{2} \mathrm{O}_{3}$ measured in our previous study which generated a type IV-like isotherm [23], all the three types of PCSs showed a significantly low water vapor adsorption uptake and a type III isotherm, showing weak interactions between adsorbent and adsorbate. On the other hand, a reference sample, sol gel-derived $\mathrm{SiO}_{2}$ generated a type I $[28,29]$-like isotherm. The slight water vapor adsorption uptake below 0.1 of $\mathrm{p} /$ $\mathrm{p}_{0}\left(\mathrm{H}_{2} \mathrm{O}\right)$ was related to capillary condensation within the micropores $[28,29]$. As shown in Fig. 1(b), the maximum amount of water vapor adsorption $\left(\mathrm{Va}\left(\mathrm{H}_{2} \mathrm{O}\right)\right)$ of the PCSs was below $4 \mathrm{~cm}^{3}(\mathrm{STP}) \mathrm{g}^{-1}$, which was much more lower than those of $\mathrm{\gamma}-\mathrm{Al}_{2} \mathrm{O}_{3}\left(297 \mathrm{~cm}^{3}(\mathrm{STP}) \mathrm{g}^{-1}\right)$ [23] and the sol gel-derived $\mathrm{SiO}_{2}\left(39.5 \mathrm{~cm}^{3}(\mathrm{STP}) \mathrm{g}^{-1}\right)$.

To examine the significantly high hydrophobic character of the PCSs in more details, FT-IR spectroscopic analysis was performed on the PCS powder samples (Fig. S2). The spectra of these samples presented common absorption peaks at $2950-2900 \mathrm{~cm}^{-1}(\mathrm{~V} \mathrm{C}-\mathrm{H}), 2100 \mathrm{~cm}^{-1}(\mathrm{~V}$ $\mathrm{Si}-\mathrm{H}), 1450-1350 \mathrm{~cm}^{-1}$ ( $\mathrm{V} \mathrm{C}-\mathrm{H}$ in $\left.\mathrm{CH}_{\mathrm{x}}(\mathrm{x}=1-3)\right), 1250 \mathrm{~cm}^{-1}$ (V
$\left.\mathrm{Si}-\mathrm{CH}_{3}\right), 1020 \mathrm{~cm}^{-1}\left(\gamma \mathrm{CH}_{2}\right.$ in Si-CH$\left.{ }_{2}-\mathrm{Si}\right)$ and around $800 \mathrm{~cm}^{-1}(\gamma$ $\mathrm{Si}-\mathrm{CH}_{3}$ and $v \mathrm{Si}-\mathrm{H}$ in $\left.\mathrm{SiC}_{4}\right)[17,22]$.

As expanded and shown in Fig. Sं2 in ESI, these samples exhibited a weak broad peak around $3400 \mathrm{~cm}^{-1}$ attributed to intermolecular hydrogen-bonded silanol ( $\mathrm{Si}-\mathrm{OH})$ group and adsorbed water molecules, while the sharp peak centered at $3674 \mathrm{~cm}^{-1}$ correspond to free $\mathrm{Si}-\mathrm{OH}$ group [22]. As discussed previously [23,30,31], the polar Si$\mathrm{OH}$ group acted as a preferential adsorption site for water molecules. Then, density of the free $\mathrm{Si}-\mathrm{OH}$ group in each sample was evaluated by measuring the relative ratio of the FT-IR absorption peak intensities: $\mathrm{I}_{\mathrm{Si}}$ $\mathrm{OH}$ at $3674 \mathrm{~cm}^{-1} / \mathrm{I}_{\mathrm{Si}-\mathrm{CH} 2-\mathrm{Si}}$ at $1020 \mathrm{~cm}^{-1}$. It was found to be as low as $0.02-0.04$. Accordingly, in addition to the hydrophobic $\mathrm{CH}_{3}$ groups attached tothe Si-Cbackbone [22], extremely low density of the free Si$\mathrm{OH}$ group lead to the superhydrophobicity of the PCSs characterized in this study.

\subsection{Properties of supported PCS membranes}

(1) Structure of PCS membranes

To confirm membrane formation of the PCS over the mesoporous $\gamma-\mathrm{Al}_{2} \mathrm{O}_{3}$ layer placed on a macroporous $\mathrm{\gamma}-\mathrm{Al}_{2} \mathrm{O}_{3}$ tubular support, SEM was performed through the observation of the cross-sectional SEM image of the alumina tubes functionalized by the PCS(UH) sample (Fig. 2). As a typical result, a thin dense layer with a uniform thickness of approximately $50 \mathrm{~nm}$ was observed on the outer surface of the mesoporous $\gamma-\mathrm{Al}_{2} \mathrm{O}_{3}$ layer which corresponds to the $\mathrm{PCS}(\mathrm{UH})$ membranes.

According to the EDS analysis for the cross-section (Fig. S3 in ESI), Si

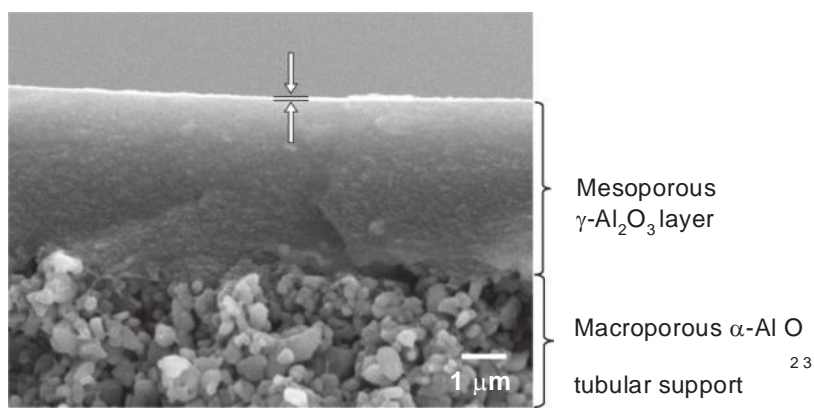

Fig. 2.A cross-sectional SEM image of PCS(UH).
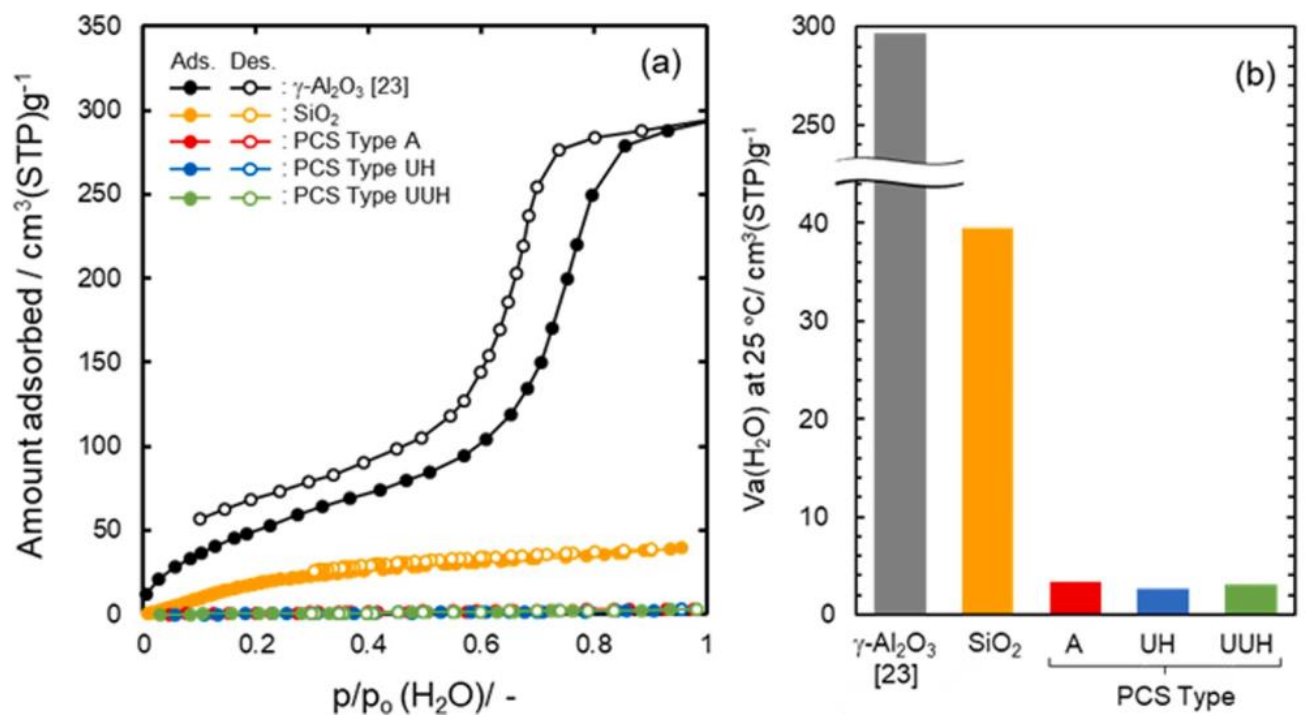

Fig. 1.Water vapor adsorption-desorption isotherms at $25{ }^{\circ} \mathrm{C}$ for (a) as-received PCSs, sol gel-derived $\mathrm{SiO}_{2}$ and mesoporous $\mathrm{\gamma}-\mathrm{Al}_{2} \mathrm{O}_{3}$ [23]. (b) Maximum amount of water vapor adsorption $\left(\mathrm{Va}\left(\mathrm{H}_{2} \mathrm{O}\right)\right)$ at $25{ }^{\circ} \mathrm{C}$ of the PCSs in comparison with those of sol gel-derived $\mathrm{SiO}_{2}$ and mesoporous $\gamma-\mathrm{Al}_{2} \mathrm{O}_{3}$ [23]. 
and Celements present in PCS were also detected within the mesoporous $\gamma-\mathrm{Al}_{2} \mathrm{O}_{3}$ layer, and it was suggested that some part of the coated PCS infiltrated the $\mathrm{\gamma}-\mathrm{Al}_{2} \mathrm{O}_{3}$ mesopore channels, but located discontinuously.

(2) Gas permeation behaviors under dry condition

Fig. 3 shows Arrhenius plots of $\mathrm{He}, \mathrm{H}_{2}$ and $\mathrm{N}_{2}$ permeances measured for the supported PCS membranes and Fig. 4 presents the effect of mean molecular weight ( $\mathrm{Mw}$ ) of starting PCS on the gas permeation properties at $50{ }^{\circ} \mathrm{C}$ of the supported PCS membranes shown in Fig. 3. Even at a low permeation temperature of $25^{\circ} \mathrm{C}$, the supported PCS membranes exhibited a relatively high $\mathrm{H}_{2}$ permeance of $8.9-12 \times 10^{-7} \mathrm{~mol} \mathrm{~m}^{-2} \mathrm{~s}^{-1}$ $\mathrm{Pa}^{-1}$ with a $\mathrm{H}_{2} / \mathrm{N}_{2}$ permselectivity $\left(\alpha\left(\mathrm{H}_{2} / \mathrm{N}_{2}\right)\right)$ of $11.5-13.7$. Furthermore, these membranes showed a similar temperature dependence of the gas permeations: all the gas permeances linearly increased with the permeation temperature, i.e. following the Arrhenius law.

As we reported previously [23], gas permeations through the supported $\mathrm{\gamma}-\mathrm{Al}_{2} \mathrm{O}_{3}$ layer itself was governed by the Knudsen's diffusion, and the $\alpha\left(\mathrm{H}_{2} / \mathrm{N}_{2}\right)$ was measured to be 3.41, which was a slight lower than the theoretical one (3.73) based on the Knudsen's diffusion. The $\alpha\left(\mathrm{H}_{2} / \mathrm{N}_{2}\right)$ values of the supported PCS membranes synthesized in this study were apparently higher than the theoretical one based on the Knudsen's diffusion. These superior $\mathrm{H}_{2}$-selectivity could be provided by the PCS top-layer. However, as shown in Fig. 4, following tendencies were found: with increasing Mw of starting PCS, each gas permeance slightly increased, while $\alpha\left(\mathrm{H}_{2} / \mathrm{N}_{2}\right)$ decreased, i.e. compared with $\mathrm{H}_{2}$, permeance of $\mathrm{N}_{2}$ preferentially increased consistently with the Mw. These results suggested that a slight but appreciable amount of $\mathrm{N}_{2}$ permeable pore channels by activated diffusion, i.e. micropore channels with a size closed to the kinetic diameter of $\mathrm{N}_{2}(0.364 \mathrm{~nm})$ [27] increased with $\mathrm{Mw}$ of the starting PCS.

The performance under dry condition of the present PCS membranes was compatible with $\mathrm{SiO}_{2}$-based organic-inorganic hybrid membranes [32]: organic methylene $\left(\mathrm{CH}_{2}\right)$ or ethylene $\left(\mathrm{CH}_{2} \mathrm{CH}_{2}\right)$ group was introduced to amorphous silica network by using 1,2-bis(triethoxysilyl) methane (BTESM) or 1,2-bis(triethoxysilyl)ethane (BTESE) as a starting silicon alkoxide for the hybrid membrane synthesis through the sol-

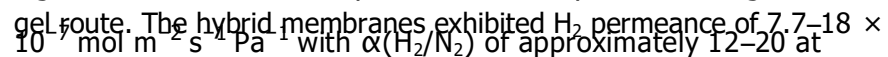

$40-50{ }^{\circ} \mathrm{C}$ [32]. However, an interesting gas permeation behavior was that, regardless of the Mw of the starting PCS, $\mathrm{H}_{2}$ permeance was highest at all permeation temperatures from 25 to $80{ }^{\circ} \mathrm{C}$, and the $\alpha\left(\mathrm{H}_{2} / \mathrm{He}\right)$ of the supported PCS membranes was measured to be 1.4-1.6 (Figs. 3 and 4).

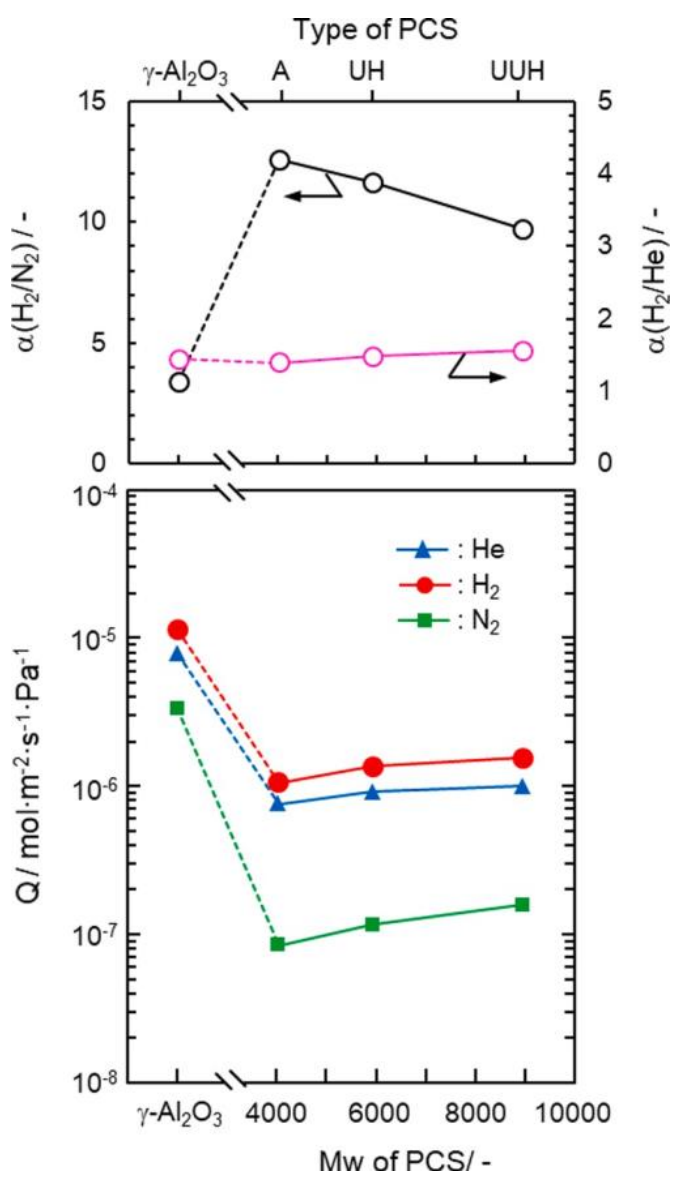

Fig. 4.Gas permeation properties at $50{ }^{\circ} \mathrm{C}$ under dry condition of PCS membranes supported on a mesoporous $\gamma-\mathrm{Al}_{2} \mathrm{O}_{3}$ layer as a function of $\mathrm{Mw}$ of starting $\mathrm{PCS}$ and those of the mesoporous $\mathrm{\gamma}-\mathrm{Al}_{2} \mathrm{O}_{3}$ layer itself placed on a macroporous $\alpha-\mathrm{Al}_{2} \mathrm{O}_{3}$ tubular support [23].

This result was unexpected because the permeance order of $\mathrm{H}_{2}>\mathrm{He}>$ $\mathrm{N}_{2}$ did not follow the kinetic diameter of gas molecule (He: $0.26 \mathrm{~nm}$, $\mathrm{H}_{2}: 0.289 \mathrm{~nm}$ and $\mathrm{N}_{2}: 0.364 \mathrm{~nm}$ ) [27]. Thus, the supported PCS membranes synthesized in this study did not show simple molecular sieve properties based on the selective permeation of smaller gas molecules through micropore channels.

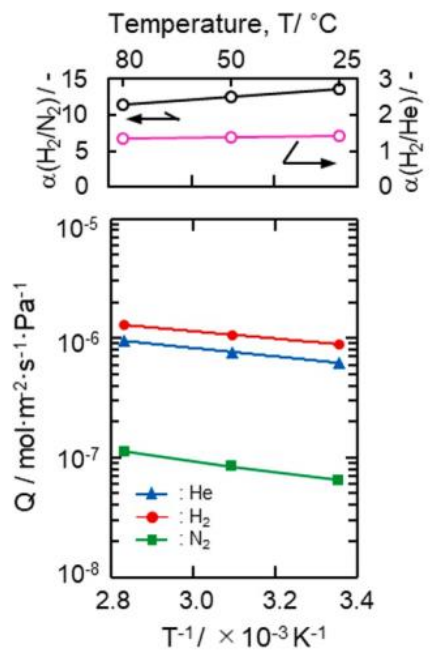

(a)

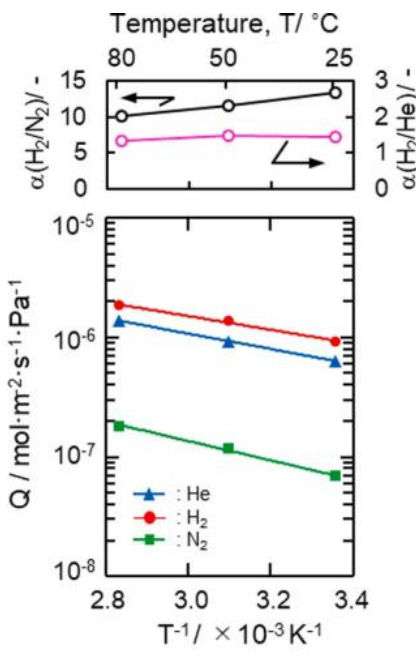

(b)

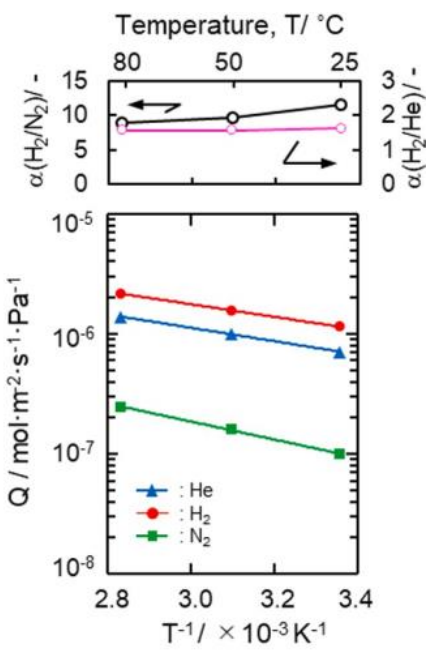

(c)

Fig. 3.Gas permeation behaviors under dry condition at 25 to $80{ }^{\circ} \mathrm{C}$ of the supported PCS membrane, (a) PCS(A), (b) PCS(UH) and (c) PCS(UUH). 
(3) Gas permeation behaviors under wet condition

Among the supported PCS membranes synthesized in this study, PCS (A) with the highest $\alpha\left(\mathrm{H}_{2} / \mathrm{N}_{2}\right)$ under dry condition was selected for further study on the gas permeation behavior under wet condition. Since the hydrogen purification process operation temperatures in the novel solar hydrogen production systems have been suggested as around $50{ }^{\circ} \mathrm{C}$ $[23,33]$, the measurements under wet condition in this study was performed at $50{ }^{\circ} \mathrm{C}$.

As shown in Fig. 5(a), all the gas permeances except water vapor gradually decreased with the water vapor partial pressure $\left(p / p_{0}\left(\mathrm{H}_{2} \mathrm{O}\right)\right)$. However, even under the saturated water vapor partial pressure $\left(p / p_{0}\right.$ $\left.\left(\mathrm{H}_{2} \mathrm{O}\right)=1\right)$ at $50{ }^{\circ} \mathrm{C}$, the $\mathrm{PCS}(\mathrm{A})$ exhibited relatively a high $\mathrm{H}_{2}$ permeance of $7.7 \times 10^{-8} \mathrm{~mol}^{-1} \mathrm{~m}^{-2} \mathrm{~s}^{-1} \mathrm{~Pa}^{-1}$.

Under the $\mathrm{p} / \mathrm{p}_{0}\left(\mathrm{H}_{2} \mathrm{O}\right)$ ranging from 0.1 to 1.0 , the $\alpha\left(\mathrm{H}_{2} / \mathrm{He}\right)$ was almost constant (1.1-1.3), while the $\alpha\left(\mathrm{H}_{2} / \mathrm{N}_{2}\right)$ increased consistently with $\mathrm{p} / \mathrm{p}_{0}\left(\mathrm{H}_{2} \mathrm{O}\right)$. Especially, above $\mathrm{p} / \mathrm{p}_{0}\left(\mathrm{H}_{2} \mathrm{O}\right)$ of 0.74 , the $\alpha\left(\mathrm{H}_{2} / \mathrm{N}_{2}\right)$ rapidly increased to reach 26 at the $p / p_{0}\left(H_{2} O \neq 1.0\right.$. Moreover, this rapid increase was found to be associated with the drastic increase in the $\alpha\left(\mathrm{H}_{2} \mathrm{O} / \mathrm{N}_{2}\right)$. At the $\mathrm{p} / \mathrm{p}_{0}\left(\mathrm{H}_{2} \mathrm{O}\right)=1.0$, the $\alpha\left(\mathrm{H}_{2} \mathrm{O} / \mathrm{N}_{2}\right)$ got to be 107 (Fig. 5 (b)).

When the measurement was performed using a $\mathrm{H}_{2}-\mathrm{N}_{2}$ (2:1) mixed feed gas (Fig. 5(c) and (d)), the p/p $p_{0}\left(\mathrm{H}_{2} \mathrm{O}\right)$ dependency up to $\mathrm{p} / \mathrm{p}_{0}$ $\left(\mathrm{H}_{2} \mathrm{O}\right)=0.74$ of the membrane performance in terms of the $\mathrm{H}_{2}$ permeance and the $\alpha\left(\mathrm{H}_{2} / \mathrm{N}_{2}\right)$ was quite similar to that characterized by measuring single gas permeances. However, under the $\mathrm{p} / \mathrm{p}_{0}\left(\mathrm{H}_{2} \mathrm{O}\right)$ above $0.74, \mathrm{~N}_{2}$ permeance intensively decreased. Finally, at the $\mathrm{p} / \mathrm{p}_{0}\left(\mathrm{H}_{2} \mathrm{O}\right)=$ 1.0 , the $\mathrm{N}_{2}$ permeance was below the limit of detection, and the PCS(A) was found to show an excellent $\mathrm{H}_{2}$-selectivity under the saturated water vapor partial pressure at $50^{\circ} \mathrm{C}$.

To investigate the gas permeation properties under the present humid conditions in more detail, the single gas permeances were measured for a reference sample, sol-gel derived $\mathrm{SiO}_{2}$ membrane formed on the same type of mesoporous $\gamma-\mathrm{Al}_{2} \mathrm{O}_{3}$-modified $\alpha-\mathrm{Al}_{2} \mathrm{O}_{3}$ macroporous support. As shown in Fig. $5(\mathrm{e})$, the $\mathrm{H}_{2}$ permeance and $\alpha\left(\mathrm{H}_{2} / \mathrm{N}_{2}\right)$ of the supported $\mathrm{SiO}_{2}$ membrane initially evaluated under dry condition at $50{ }^{\circ} \mathrm{C}$ were $7.1 \times 10^{-8} \mathrm{~mol}^{-1} \mathrm{~m}^{-2} \mathrm{~s}^{-1} \mathrm{~Pa}^{-1}$ and 39 , respectively. Under wet condition, all the gas permeances immediately decreased at $\mathrm{p} / \mathrm{p}_{0}$ $\left(\mathrm{H}_{2} \mathrm{O}\right)=0.1$, then consistently decreased with $\mathrm{p} / \mathrm{p}_{0}\left(\mathrm{H}_{2} \mathrm{O}\right)$. Finally, at $\mathrm{p} /$ $\mathrm{p}_{0}\left(\mathrm{H}_{2} \mathrm{O}\right)=1$, the He permeance was $2.1 \times 10^{-9} \mathrm{~mol}^{-1} \mathrm{~m}^{-2} \mathrm{~s}^{-1} \mathrm{~Pa}^{-1}$, while the $\mathrm{H}_{2}$ and $\mathrm{N}_{2}$ permeances were below the limit of detection.

It was well known that microporous $\mathrm{SiO}_{2}$ membranes having molecular-sieving properties were beneficial to $\mathrm{H}_{2}$ separation [9,34-38] Actually, under the initial dry condition, the smaller kinetic diameter below $0.3 \mathrm{~nm}$ of the permeate gas was, the higher permeance through the present sol-gel derived $\mathrm{SiO}_{2}$ membrane showed.

The kinetic diameter of $\mathrm{H}_{2} \mathrm{O}$ molecule was reported as $0.265 \mathrm{~nm}$ [27], sufficiently smaller than the suggested mean diameter of gaspermeable micropore channels within $\mathrm{SiO}_{2}(0.3 \mathrm{~nm}$ [9]). Water vapor could permeate through the $\mathrm{SiO}_{2}$ membrane, which lead to the plugging of gas-permeable micropore channels by adsorption and subsequent capillary condensation of $\mathrm{H}_{2} \mathrm{O}$ molecules as the permeate $[5,10,11]$; the apparent decrease in gas permeances by presence of the minute water vapor $\left(p / p_{0}\left(\mathrm{H}_{2} \mathrm{O}\right)=0.1\right)$ agreed well with the hydrophilic characteristics of the sol-gel derived $\mathrm{SiO}_{2}$ shown in Fig. 1(a).

However, the rapid degradation under the higher humid condition
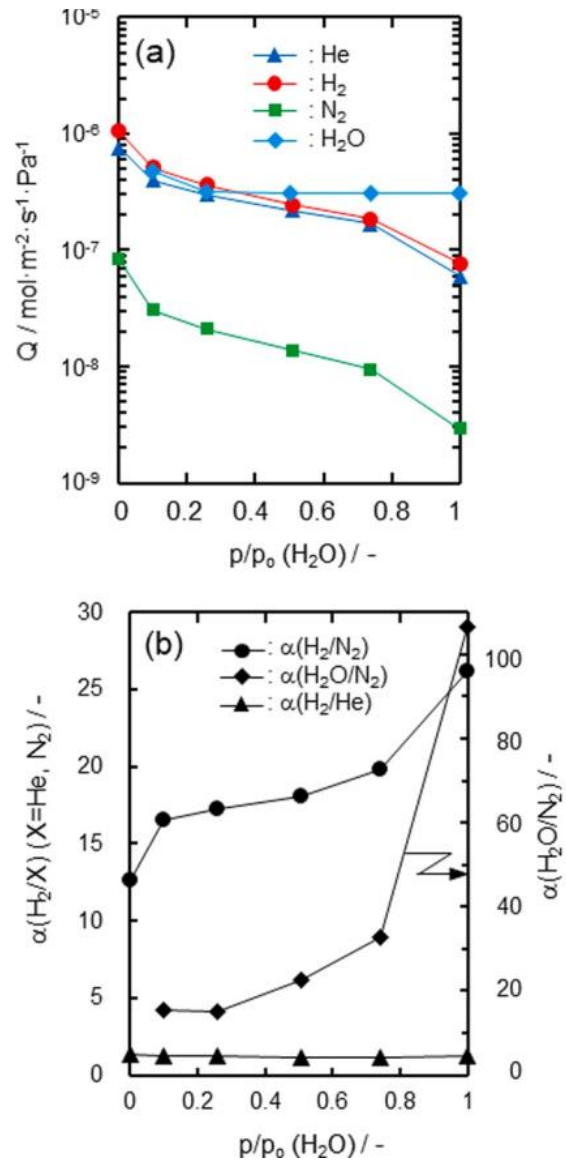
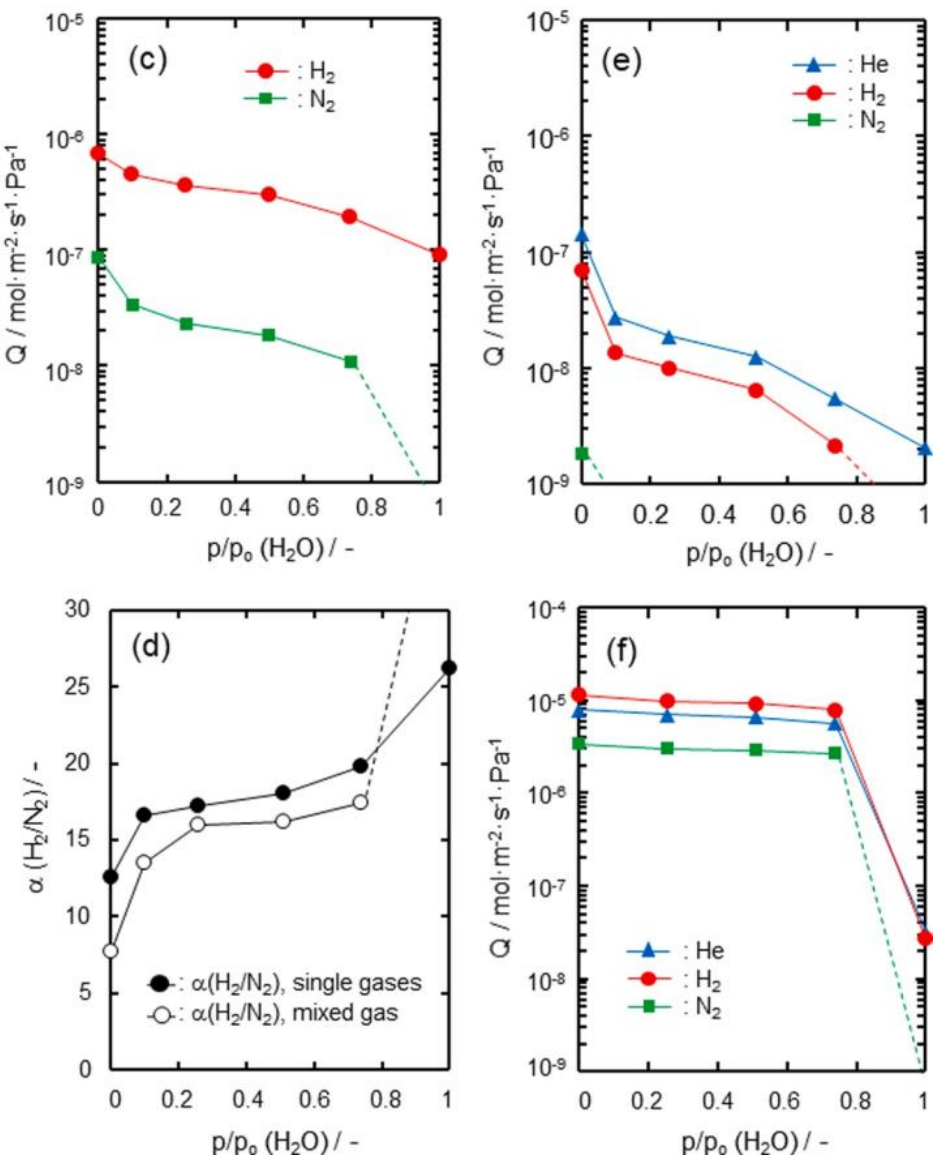

Fig. 5.Gas permeances and water vapor permeance at $50{ }^{\circ} \mathrm{C}$ evaluated for $\mathrm{PCS}(\mathrm{A})$ under $\mathrm{p} / \mathrm{p}_{0}\left(\mathrm{H}_{2} \mathrm{O}\right)$ ranging from 0 to 1.0 . The evaluation was performed by using (a), (b) single gases of $\mathrm{He}, \mathrm{H}_{2}$ and $\mathrm{N}_{2}$ and (c) a mixed gas of $\mathrm{H}_{2}$ and $\mathrm{N}_{2}$ in the molar ratio 2:1. (d) Comparison of $\alpha\left(\mathrm{H}_{2} / \mathrm{N}_{2}\right)$ values evaluated based on the single gas permeances and those by using the $\mathrm{H}_{2}-\mathrm{N}_{2}(2: 1)$ mixed feed gas. Gas permeances evaluated for reference samples, (e) supported $\mathrm{SiO} 2$ membrane and (f) supported mesoporous $\gamma-\mathrm{Al}_{2} \mathrm{O}_{3}$ membrane itself [23] under $\mathrm{p} / \mathrm{p}_{\mathrm{o}}\left(\mathrm{H}_{2} \mathrm{O}\right)$ ranging from 0 to 1.0 at $50{ }^{\circ} \mathrm{C}$. 
above $\mathrm{p} / \mathrm{p}_{0}\left(\mathrm{H}_{2} \mathrm{O}\right)$ of 0.5 was inconsistent with the $\mathrm{H}_{2} \mathrm{O}$ adsorption behavior shown in Fig. 1(a): At around p/p $\left(\mathrm{p}_{2} \mathrm{O}\right)=0.4$, the amount of water vapor adsorption measured for the $\mathrm{SiO}$, reached maximum, while both $\mathrm{He}$ and $\mathrm{H}_{2}$ permeances decreased rather rapidly above $\mathrm{p} / \mathrm{p}_{0}\left(\mathrm{H}_{2} \mathrm{O}\right)$

$=0.5$ ( Fig. 5(e)). This was due to the high hydrophilicity of the mesoporous $\gamma-\mathrm{Al}_{2} \mathrm{O}_{3}$ layer beneath the $\mathrm{SiO}_{2}$ membrane. As we reported in our previous study [23], above $\mathrm{p} / \mathrm{p}_{0}\left(\mathrm{H}_{2} \mathrm{O}\right) 0.4$, the water vapor adsorption-desorption isotherm for the sol-gel derived mesoporous $\gamma$ $\mathrm{Al}_{2} \mathrm{O}_{3}$ exhibited a large hysteresis loop assigned to capillary condensation of $\mathrm{H}_{2} \mathrm{O}$ molecules within mesopores, which lead to the drastic decrease in gas permeances through the supported mesoporous $\gamma-\mathrm{Al}_{2} \mathrm{O}_{3}$ layer itself under the high-humidity conditions at $50{ }^{\circ} \mathrm{C}$ (Fig. 5(f) [23]). Accordingly, in addition to the intrinsic degradation by the permeate $\mathrm{H}_{2} \mathrm{O}$-induced plugging within the $\mathrm{SiO}_{2}$ membrane, gas permeations through the supported $\mathrm{SiO}_{2}$ membrane could be intensively restricted by condensation of the permeate $\mathrm{H}_{2} \mathrm{O}$ molecules within mesopores located close to the hetero interface between the $\mathrm{\gamma}-\mathrm{Al}_{2} \mathrm{O}_{3}$ layer and the top surface $\mathrm{SiO}_{2}$ membrane.

As shown in Fig. 5(a), the PCS(A) exhibited a relatively high water vapor permeance of $3.1 \times 10^{-7} \mathrm{~mol}^{-1} \mathrm{~m}^{-2} \mathrm{~s}^{-1} \mathrm{~Pa}^{-1}$ at the $\mathrm{p} / \mathrm{p}_{0}\left(\mathrm{H}_{2} \mathrm{O}\right)=$ 1.0. This value was compatible with that previously measured for the supported mesoporous $\mathrm{\gamma}-\mathrm{Al}_{2} \mathrm{O}_{3}$ layer itself $\left(7.10^{-7} \mathrm{~mol}^{-1} \mathrm{~m}^{-2} \mathrm{~s}^{-1}\right.$ $\mathrm{Pa}^{-1}$ ) [23]. Thus, gas permeation property of the $\mathrm{PCS}(\mathrm{A})$ could be also affected by the highly hydrophilic character of the mesoporous $\gamma-\mathrm{Al}_{2} \mathrm{O}_{3}$ layer. However, an interesting point was that the affection in terms of the decrease in permeance under the high-humidity conditions was mainly observed for $\mathrm{N}_{2}$ gas, and such affection was more pronounced when the gas permeation measurement was performed by using a mixed $\mathrm{H}_{2}-\mathrm{N}_{2}(2: 1)$ gas (Fig. 5(c)). These results suggested that the dominant permeation of $\mathrm{N}_{2}$ and water vapor was diffusion through micropore channels within the PCS top-layer network. Under higher humid conditions above $\mathrm{p} / \mathrm{p}_{0}\left(\mathrm{H}_{2} \mathrm{O}\right)=0.74, \mathrm{~N}_{2}$ permeation was thought to be restricted by the highly hydrophilic mesoporous $\mathrm{\gamma}-\mathrm{Al}_{2} \mathrm{O}_{3}$ layer as in the case of the supported $\mathrm{SiO}_{2}$ membrane discussed above. On the other hand, the $\mathrm{He}$ and $\mathrm{H}_{2}$ permeationsthrough the $\mathrm{PCS}(\mathrm{A})$ werethoughtto be governed by diffusion through the hydrophobic and dense PCS top-layer network where neither $\mathrm{H}_{2} \mathrm{O}$ nor $\mathrm{N}_{2}$ could permeate.

\subsection{Analysis of gas permeation behaviors}

\section{(1) He and $\mathrm{H}_{2}$ permeations}

In order to quantitatively explain the mechanism of $\mathrm{He}$ and $\mathrm{H}_{2}$ permeation through the PCS top-layer network, the $\mathrm{He}$ and $\mathrm{H}_{2}$ permeances were measured at room temperature to $200{ }^{\circ} \mathrm{C}$ (sufficiently high above $150{ }^{\circ} \mathrm{C}$ to examine the affection by physisorption of gas molecules [37,38]), and analyzed using a solid-state diffusion model [39-42]. In this analysis, another membrane sample, PCS(UH) having a higher m.p. $\left(350{ }^{\circ} \mathrm{C}\right)$ was adopted.

Solid-state diffusion occurs with further decrease in the pore size than Knudsen diffusion occurs, where the gas molecule interacts strongly with the membrane material behaving as a dense material. In this case, the solubility of the gas molecule is necessary to consider, so that the molecules permeance through the membrane (Q) can be expressed by the product of the solubility and the diffusivity. The solubility $(S)$ is derived from the equilibrium between the solubility sites and the gaseous phase [43]. The diffusivity (D) is supposed that the process of gas atom movement between solubility sites in the membrane is a random walk process with an equilibrium established between atoms in solubility sites and those moving between sites [44]. Gas molecules, vibrating at solubility sites with a characteristic frequency, jump to an adjacent solubility site by surmounting a potential barrier. The permeance $(Q=S D)$ is given by following equation, considering the effect of rotation of polyatomic gas molecule:
$\mathrm{Q}_{s s}=\frac{d^{2} h^{2}}{6 L} \frac{1}{2 \pi m k T}^{\mathrm{J}_{\frac{3}{2}}} \frac{\sigma h^{2}}{8 \pi^{2} I k T} \times \frac{\left(N_{S} / N_{A}\right)}{e^{h v^{*} 2 k T} e^{h V^{*} 2 k T} 2^{-\Delta E_{s s}}}$

where $Q_{s s}$ is the permeance through the membrane $\left[\mathrm{mol} \mathrm{m} \mathrm{m}^{-2} \mathrm{~s}^{-1} \mathrm{~Pa}^{-1}\right]$, $d$ is jump distance [m], $h$ is Planck's constant $\left[\mathrm{m}^{2} \mathrm{~kg} \mathrm{~s}^{-1}\right], L$ is the thickness of the membrane [m], $m$ is the mass [kg], $\mathrm{v} *$ is vibrational frequency of the gas molecules in the passageways between the sorption sites $\left[\mathrm{s}^{-1}\right], k$ is Boltzmann's constant $\left[\mathrm{J} \mathrm{K}^{-1}\right], T$ is the temperature $[\mathrm{K}], \sigma$ is the symmetry factor of the species $\left(\sigma=2\right.$ for $\left.\mathrm{H}_{2}\right), I$ is the moment of inertia $\left[\mathrm{kg} \mathrm{m}^{2}\right], N_{S}$ is number of solubility sites per area $\left[\mathrm{m}^{-3}\right], N_{A}$ is Avogadro's number [mol $\left.{ }^{-1}\right], \Delta E_{s s}$ is activation energy for permeation [] $\left.\mathrm{mol}^{-1}\right], \alpha$ is an exponent accounting for incomplete loss of rotation ( $\alpha=$ 0 for monoatomic molecule, $\mathrm{He}$, and $\alpha=0.2$ for polyatomic molecule, $\left.\mathrm{H}_{2}\right), R$ is the gas constant $\left[\mathrm{J} \mathrm{mol}^{-1} \mathrm{~K}^{-1}\right]$.

As shown in Fig. 6(a), at all temperatures up to $200{ }^{\circ} \mathrm{C}(473 \mathrm{~K})$, the experimental permeance of $\mathrm{H}_{2}$ was higher than that of $\mathrm{He}$, and each gas permeance monotonously increased with the permeation temperature. Then, the temperature dependence of the $\mathrm{He}$ and $\mathrm{H}_{2}$ permeances were fitted to the non-linear curve by the Eq. (2) with three free parameters, $N_{s}, \mathrm{~V}^{*}$ and $\Delta E_{s s}$ which were determined using Igor Pro 7.00 (wavemetrics, Inc., OR, USA). The membrane thickness $(L)$ was $50 \mathrm{~nm}$ as obtained from the SEM image shown in Fig. 2 and jump distance $(d)$ was $0.8 \mathrm{~nm}$ which was used by following previous reports $[39,45]$. The calculated permeances of $\mathrm{He}$ and $\mathrm{H}_{2}$ were well consistent with experimental data, so that the solid-state diffusion model fitting analysis was to be made appropriately.

The fitting parameters obtained in this study were listed in Table 2, and compared with those for $\mathrm{H}_{2}$-selective amorphous ceramic membranes previously reported by other research groups: polysiloxanederived amorphous silicon oxycarbide (SiOC) membrane (\#01) synthesized by pyrolysis at $700{ }^{\circ} \mathrm{C}$ in $\mathrm{Ar}$ [45], and CVD-derived $\mathrm{SiO}_{2}$ membranes (\#02 05) having different microporosity which Oyama et al. $[41,42,46,47]$ systematically synthesized by varying the organic ligand of starting $\mathrm{Si}$ alkoxide precursor and CVD process temperature in Ar: \#02 [46] and \#03 [41] (tetraethoxysilane (TEOS) at $600{ }^{\circ} \mathrm{C}$ ), \#04 (vinyltriethoxysilane (VTES) at $600{ }^{\circ} \mathrm{C}$ ) [42], \#05 (35\% trimethylmethoxysilane (TMMOS) -TEOS at $650{ }^{\circ} \mathrm{C}$ ) [47].

There were two criteria for this curve fitting study: (1) $N_{S}$, the number of solubility sites should be in inverse relation to the kinetic diameter of the permeate gas molecule because the larger gas molecule could not fit into more solubility sites, and thus $N_{S}$ for $\mathrm{H}_{2}(0.289 \mathrm{~nm})<$ $N_{S}$ for He $(0.26 \mathrm{~nm})$. (2) $\mathrm{v}^{*}$, the vibrational frequency should be higher for the permeate gas having the smaller molecular weight, i.e., $v^{*}$ for $\mathrm{H}_{2}$ $\left(2.02 \mathrm{~g} \mathrm{~mol}^{-1}\right)>\mathrm{v}^{*}$ for $\mathrm{He}\left(4.00 \mathrm{~g} \mathrm{~mol}^{-1}\right)$. As shown in Table 2, the values of $N_{S}$ and $\mathrm{V}^{*}$ estimated for $\mathrm{He}$ and $\mathrm{H}_{2}$ permeations through the $\mathrm{PCS}(\mathrm{UH})$ corresponded to the physical constants mentioned above, and similar to those previously reported for the membranes composed of SiOC (\#01) [45] or $\mathrm{SiO}_{2}$ (\#02 05) $[41,42,46,47]$.

Due to several differences in material factors of the network which composing active separation layer such as chemical composition and density, it was difficult to discuss on the difference in the fitting parameters, however, the values of $N_{S}$ for $\mathrm{He}$ and $\mathrm{H}_{2}$ permeations through the present PCS top-layer were compatible with those reported for the CVD-derived $\mathrm{SiO}_{2}$ membrane (\#05) with relatively low density, fabricated by using stating Si alkoxides having organic ligands such as 35\% TMMOS-TEOS [47]. On the other hand, the $\mathrm{v}^{*}$ values for both $\mathrm{He}$ and $\mathrm{H}_{2}$ were apparently lower than those reported for the CVD-derived $\mathrm{SiO}_{2}$ membranes (\#02 05) [41,42,46,47], but were approximately one order of magnitude higher than those reported for the polymer-derived SiOC membrane (\#01) [45].

One unique result was the $\Delta E_{s s}$, activation energy obtained for the present PCS top-layer. $\Delta E_{s s}$ has an inverse relationship with $N_{S}$ physically, because the larger molecules must overcome a larger energy barrier to migrate through the membrane. In this context, all the data reported for the $\mathrm{SiO}_{2}$ membranes (\#02 05) followed this relation, and 


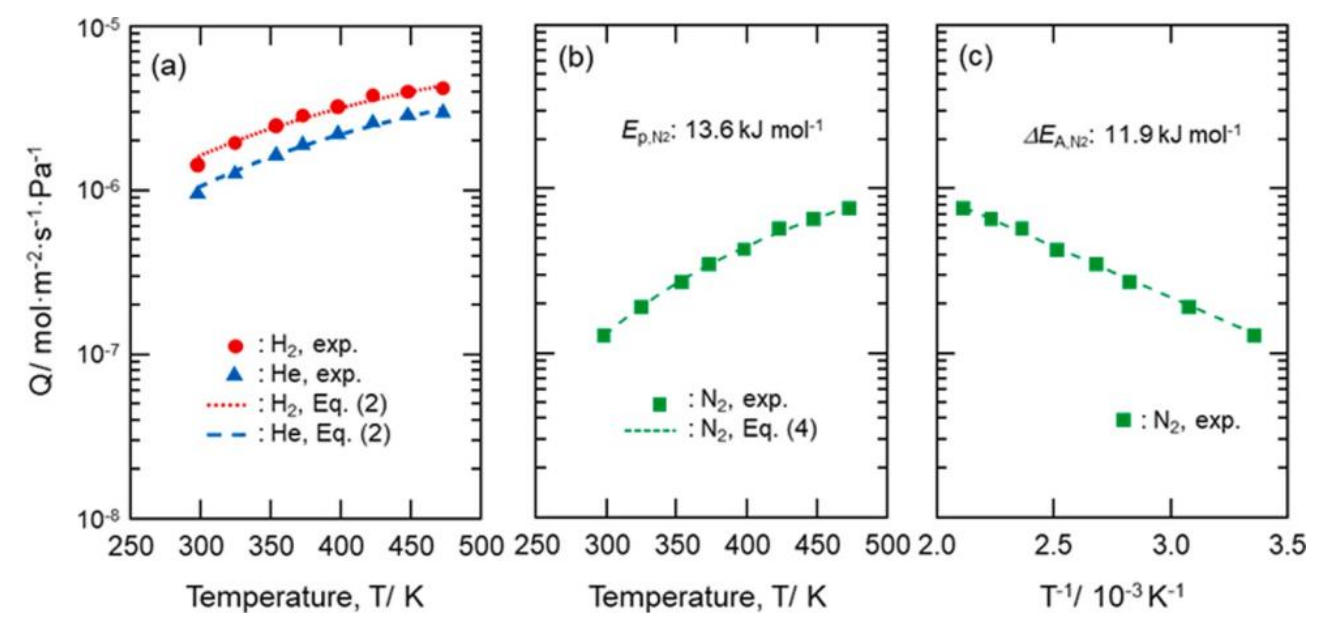

Fig. 6.Study on temperature dependence of gas permeances through the PCS(UH) at room temperature to $473 \mathrm{~K}$ (200 ${ }^{\circ} \mathrm{C}$ ). Comparison of experimentally evaluated (a) $\mathrm{H}_{2}$ and He permeances with those calculated using solid-state diffusion model (Eq. (2)) and (b) $\mathrm{N}_{2}$ permeances with those calculated based on the modified gastranslational diffusion model (Eq. (4)). (c) Arrhenius plot of the experimentally evaluated $\mathrm{N}_{2}$ permeances.

Table 2

Comparison of $\mathrm{H}_{2}$ permeation properties and fitting parameters.

\begin{tabular}{|c|c|c|c|c|c|c|c|c|c|c|c|}
\hline \multirow[t]{2}{*}{ No. } & \multirow[t]{2}{*}{ Membrane } & \multicolumn{4}{|c|}{$\mathrm{H}_{2}$ permeation properties } & \multicolumn{2}{|c|}{$N_{s} / 10^{25} \mathrm{~m}^{-3}$} & \multicolumn{2}{|c|}{$v^{*} / 10^{12} \mathrm{~s}^{-1}$} & \multicolumn{2}{|c|}{ 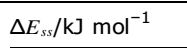 } \\
\hline & & $\mathrm{T} / \mathrm{K} Q \mathrm{H}$ & $2 / \mathrm{mol} \mathrm{m}^{-2} \mathrm{~s}^{-1} \mathrm{~Pa}^{-1}$ & $\alpha\left(\mathrm{H}_{2} / \mathrm{X}\right) /-$ & $x$ & $\mathrm{He}$ & $\mathrm{H}_{2}$ & $\mathrm{He}$ & $\mathrm{H}_{2}$ & $\mathrm{He}$ & $\mathrm{H}_{2}$ \\
\hline This work & $\mathrm{PCS}(\mathrm{UH})$ & 323 & $1.4 \times 10^{-6}$ & 11.7 & $\mathrm{~N}_{2}$ & 15.0 & 11.0 & 0.60 & 0.66 & 5.9 & 5.8 \\
\hline \#01 & $\mathrm{SiOC}[45]$ & 573 & $1.78 \times 10^{-8}$ & 22.4 & $\mathrm{~N}_{2}$ & 1.3 & 0.76 & 0.082 & 0.089 & 8.5 & 7.9 \\
\hline \#02 & $\mathrm{SiO}_{2}[46]$ & 873 & $1.2 \times 10^{-7}$ & 1800 & $\mathrm{CO}$ & 74.0 & 27.3 & 7.77 & 8.10 & 8.0 & 12.8 \\
\hline \#03 & $\mathrm{SiO}_{2}[41]$ & 873 & $5.0 \times 10^{-7}$ & 5100 & $\mathrm{CO}$ & 62 & 38 & 7.0 & 7.3 & 4.2 & 10.4 \\
\hline \#04 & $\mathrm{SiO}_{2}[42]$ & 873 & $5.4 \times 10^{-7}$ & 150 & $\mathrm{~N}_{2}$ & 47.5 & 33.5 & 2.21 & 2.39 & 3.4 & 7.3 \\
\hline \#05 & $\mathrm{SiO}_{2}[47]$ & 923 & $1.1 \times 10^{-6}$ & 53 & $\mathrm{~N}_{2}$ & 15.7 & 8.7 & 2.94 & $3.02-0.08$ & & \\
\hline
\end{tabular}

the $\Delta E_{s s}$ for $\mathrm{H}_{2}$ permeation was apparently higher than that of $\mathrm{He}$ $[41,42,46,47]$. On the other hand, the $\Delta E_{s s}$ for $\mathrm{H}_{2}$ permeation through the PCS top-layer was evaluated as $5.8 \mathrm{~kJ} \mathrm{~mol}^{-1}$ and found to be rather slight lower than that for the He permeation $\left(5.9 \mathrm{~kJ} \mathrm{~mol}^{-1}\right)$. This result corresponded well with the unique $\mathrm{H}_{2}$-permselectivity experimentally observed for the PCS(UH), $\mathrm{H}_{2}$ permeance increased consistently with temperature, and at all temperatures up to $200{ }^{\circ} \mathrm{C}$, the permeance of $\mathrm{H}_{2}$ was higher than that of the smaller gas molecule of He (Fig. 6(a)).

Gurlo et. al reported that the polymer-derived SiOCmembrane(\#01) exhibited a similar $\mathrm{H}_{2}$-permselectivity, and as shown in Table 2, their fitting study also resulted in the irregular relation, $\Delta E_{s s} / \mathrm{kJ} \mathrm{mol}^{-1}$ for $\mathrm{He}$ permeation (8.5) $>$ for $\mathrm{H}_{2}$ permeation (7.9) [45]. The PCS top-layer investigated in this study was ternary $\mathrm{SiCH}$ organic-inorganic hybrid polymer composed $\mathrm{Si}-\mathrm{C}$ backbone substituted with considerable amount of $\mathrm{CH}_{3}$ groups. Accordingly, it was suggested that the existence of such hydrocarbon groups allowed preferential dissolution and subsequent diffusion of $\mathrm{H}_{2}$ explained by the solid-state diffusion mechanism dis$\mathrm{H}_{2}$ permeation Mrougher the was found that the $\Delta E_{s s}\left(5.8 \mathrm{~kJ} \mathrm{~mol}^{-1}\right)$ for the

those (16.3-16.7 kJ mol${ }^{-1}$ ) of silicon oxycarbide (SiOC) membranes derived from polydimethylsilane (PMS) reported by Tsai et al. [48]. According to the reported membrane syntheses route, prior to the final pyrolysis at $300-600{ }^{\circ} \mathrm{C}$, PMS was thermally converted to PCS via the Kumada rearrangement during the heat treatment at $460{ }^{\circ} \mathrm{C}$ for $14 \mathrm{~h}$ under Ar, then cured at $200{ }^{\circ} \mathrm{C}$ in air for $1 \mathrm{~h}$. The PCS formed in-situ could be highly reactive to be well cross-linked during the long-time heat treatment at $460{ }^{\circ} \mathrm{C}$. Moreover, the heat-treated PCS became infusible via $\mathrm{Si}-\mathrm{O}-\mathrm{Si}$ bond formations by the subsequent curing in air. These thermal treatments led to the formation of dense network like microporous amorphous $\mathrm{SiO}_{2}$ in spite of the final low-temperature pyrolysis at 300 to $600{ }^{\circ} \mathrm{C}$.

\section{(2) $\mathrm{N}_{2}$ permeation}

In addition to $\mathrm{He}$ and $\mathrm{H}_{2}$ permeances, the temperature dependence of $\mathrm{N}_{2}$ permeance was measured for the same PCS(UH). As shown in Fig. 6 (b), N2 permeance also increased consistently with permeation temperature.

As discussed above, the dominant permeation of $\mathrm{N}_{2}$ could be diffusion through micropore channels within the PCS top-layer network. Then, the temperature dependence of the $\mathrm{N}_{2}$ permeance was examined using a permeation model equation recently proposed by Yoshioka et al. [37], which considering the effect of the potential field in a micropore

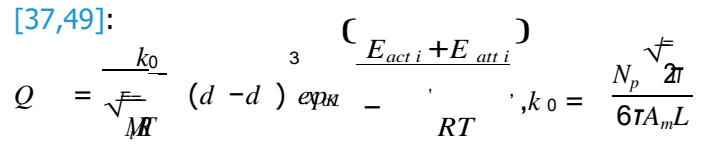

where $Q_{c K L}\left[\mathrm{~mol} \mathrm{~m}^{-2} \mathrm{~s}^{-1} \mathrm{~Pa}^{-1}\right]$ is the Knudsen permeance of gas molenetles of that are wall, concentrated by the attractive nature of the motential

$i$-th component [m], $N_{p}$ is the number of pores with pore diameters of $d_{0}$ on the membrane, $\mathrm{T}$ is the tortuosity $[-], A_{m}$ is the membrane area $\left[\mathrm{m}^{2}\right]$, $L$ is the thickness of the membrane [m], $M_{i}$ is the molar weigh of the $i$-th diffusing gas component $\left[\mathrm{kg} \mathrm{mol}^{-1}\right], E_{\text {act }, i}$ is the activation energy for the permeation of the $i$-th component $\left[\mathrm{J} \mathrm{mol}^{-1}\right], E_{\text {att },}$ is the attractive potential energy for the $i$-th component $\left[\mathrm{J} \mathrm{mol}^{-1}\right], R$ is the gas constant [] $\left.\mathrm{mol}^{-1} \mathrm{~K}^{-1}\right]$, and $T$ is the permeation temperature $[\mathrm{K}]$.

Eq. (3) is a modified gas-translational (GT) diffusion [50-52] (mGT) model equation with the additional consideration of the effective diffusion length $\left(d_{0} t_{i}\right)$ and provides a more detailed description of the gas permeation model equation by considering activation energy, adsorption energy and size of permeate gas molecule. Accordingly, the mGT model can be expected to achieve universal understandings of the permeation mechanisms in a micropore from Knudsen diffusion to 
activated diffusion $[37,49]$.

In this study, $Q_{c K L}$ was renamed as $Q_{m G T}$ and expressed by simplifying Eq. (3) as:

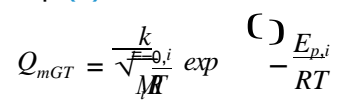

where $k_{0, i}=k_{o}\left(d_{0^{-}} d_{i}\right)^{3}$, and $E_{\mathrm{p}, i}=E_{a c t, i}+E_{a t t, i}$. Then, the value of $E_{\mathrm{p}, i}$ for the $\mathrm{N}_{2}$ permeation was estimated by fitting Eq. (4) to the experimentally obtained temperature dependency data with two free parameters, $k_{0, i}$ and $E_{\mathrm{p}, i}$. These parameters were also determined using Igor Pro7.00. As shown in Fig. 6(b), the calculated permeance of $\mathrm{N}_{2}$ was well consistent with experimental data, and the fitting parameter, $E_{\mathrm{p}, i}$ wasfound as 13.6 $\mathrm{kJ} \mathrm{mol}{ }^{-1}$.

As we reported previously, the PCSs exhibited extremely low affinity toward $\mathrm{N}_{2}$, and it was impossible to measure the BET (Bru- nauerEmmett-Teller) surface area by using $\mathrm{N}_{2}$ as a probe molecule at $77 \mathrm{~K}[31]$. Accordingly, even at room temperature, the $E_{a t t, N 2}$ could be negligibly small, and thus $E_{\mathrm{p}, N 2} \approx E_{a c t, N 2}$. Moreover, the $E_{\mathrm{p}, N 2}$ was compatible with the activation energy for $\mathrm{N}_{2}$ permeation $\left(\Delta E_{\mathrm{A} . N 2}, 11.9\right.$ $\mathrm{kJ} \mathrm{mol}^{-1}$ ) obtained by the Arrhenius plot (Fig. 6(c)). The dominant mechanism for the $\mathrm{N}_{2}$ permeation could be recognized as activated diffusion, which indicated that the PCS top-layer had a microporosity with the size of pore channels close to the kineticC diameter of $\mathrm{N}_{2}$ gas

molecule $(0.364 \mathrm{~nm})$.

(3) Effect of water vapor partial pressure on gas permeations

A schematic diagram of Fig. 7 presents possible gas permeation be-

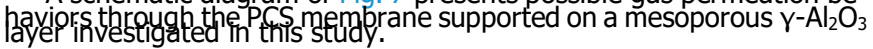
$\mathrm{He}$ and $\mathrm{H}_{2}$ dominantly permeated through the dense PCS top-layer Kinetic diameter / nm

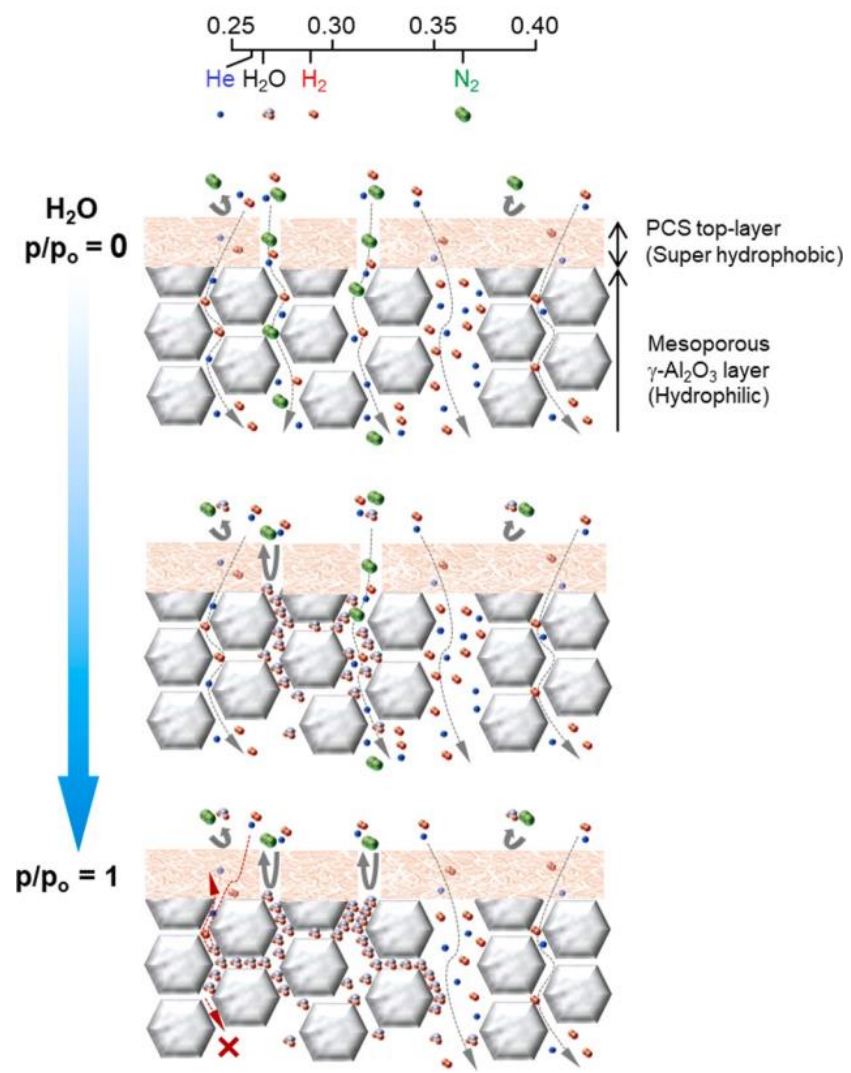

Fig. 7.Schematic of gas permeation behaviors through a PCS membrane supported on a mesoporous $\mathrm{\gamma}-\mathrm{Al}_{2} \mathrm{O}_{3}$ layer under dry and wet conditions at $50{ }^{\circ} \mathrm{C}$. network governed by the solid-state diffusion mechanism, while the dominant $\mathrm{N}_{2}$ permeation was activated diffusion through the micropore channels within the PCS network. The size of the micropore channels could be close to the kinetic diameter of $\mathrm{N}_{2}\left(d_{\mathrm{N} 2}, 0.364 \mathrm{~nm}\right)$ [27].

The kinetic diameter of water vapor $\left(\mathrm{H}_{2} \mathrm{O}\right.$ molecule, $\left.0.265 \mathrm{~nm}\right)[27]$ was sufficiently smaller than $d_{\mathrm{N} 2}$. Moreover, the PCS was highly hydrophobic, which allowed stable water vapor permeation through the $\mathrm{N}_{2}$-permeable micropore channels within the PCS top-layer. However, immediate adsorption and subsequent condensation of the permeate $\mathrm{H}_{2} \mathrm{O}$ molecules could proceed at the entrance to the highly hydrophilic mesoporous $\gamma-\mathrm{Al}_{2} \mathrm{O}_{3}$ layer beneath the PCS top-layer, i.e. at the hetero interface between the PCS layer and mesoporous $\gamma-\mathrm{Al}_{2} \mathrm{O}_{3}$ layer.

Then, the relationship between the $\mathrm{p} / \mathrm{p}_{0}\left(\mathrm{H}_{2} \mathrm{O}\right)$ and degree of the permeate $\mathrm{H}_{2} \mathrm{O}$-induced plugging was examined in the following attempt: The entrance to the mesoporous $\gamma-\mathrm{Al}_{2} \mathrm{O}_{3}$ layer was treated as a cylindrical pore having a mean effective diameter, $d_{\text {ent }}$. Under the $\mathrm{p} / \mathrm{p}_{0}\left(\mathrm{H}_{2} \mathrm{O}\right)$ ranging from 0.1 to 1.0 , the $d_{\text {ent. }}$ was estimated by calculating the normalized Knudsen-based permeance (NKP) $f_{N K P}$, which is defined as the ratio of the permeance of a target component $\left(Q_{i}\right)$ to standard gas permeance $\left(Q_{S}\right)$, that considers the contribution of molar weight can be given as a function of gas molecular size, $d_{i}$ by measuring the gas permeances of several gases at a given constant temperature [37],

$$
\begin{aligned}
& \text { 言 } \quad(d-d)^{3} \exp -\underset{\text { Epp,i }}{(} \quad(=)_{3}
\end{aligned}
$$

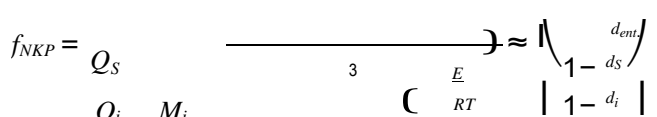

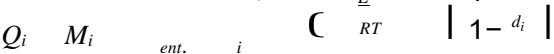

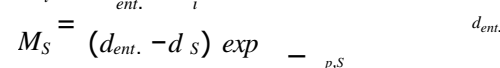

$R T$

Under the limiting conditions of $d_{s}<d_{i}<d_{\text {ent., }}$ kinetic diameter

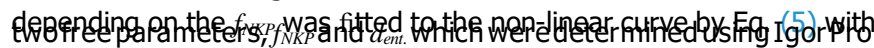
7.00. The vales of $f_{N K P}$ were calculated using the permeance through the PCS $(A)$ under dry and wet condition at $323 \mathrm{~K}\left(50{ }^{\circ} \mathrm{C}\right)$ shown in Fig. $5(\mathrm{a})$. The permeance and molecular size of He were adopted as $Q_{s}$ and $d_{S}$, respectively. In this estimation, the plots for $\mathrm{H}_{2} \mathrm{O}$ and $\mathrm{H}_{2}$ were excluded from the fitting, because $\mathrm{H}_{2} \mathrm{O}$ was condensable under the present wet condition, while $\mathrm{H}_{2}$ preferentially permeated through the PCStop-layer. The results are shown in Fig. S4 in ESI. For comparison, the $f_{N K P}$ values for $\mathrm{H}_{2} \mathrm{O}$ and $\mathrm{H}_{2}$ were marked or listed in this graph. The $d_{\text {ent }}$. under the initial dry condition was estimated as $0.57 \mathrm{~nm}$, then got to be smaller consistently with the $\mathrm{p} / \mathrm{p}_{0}\left(\mathrm{H}_{2} \mathrm{O}\right)$. Finally, the $d_{\text {ent. }}$ at $\mathrm{p} / \mathrm{p}_{0}\left(\mathrm{H}_{2} \mathrm{O}\right) \neq .0$ was estimated as $0.47 \mathrm{~nm}$.

The $d_{\text {ent. }}$ values estimated were indeed large enough for all the gases of $\mathrm{He}, \mathrm{H}_{2}$ and $\mathrm{N}_{2}$ to permeate through, but plugging of a certain fraction of the entrance having a much smaller diameter (closed to $d_{N 2}, 0.364$ $\mathrm{nm}$ ) could proceed under the high-humidity conditions of $\mathrm{p} / \mathrm{p}_{0}\left(\mathrm{H}_{2} \mathrm{O}\right)>$ 0.5 at $50{ }^{\circ} \mathrm{C}$

As shown in Fig. 5(a), there was a tendency that all the gas permeances decreased with increasing $\mathrm{p} / \mathrm{p}_{0}\left(\mathrm{H}_{2} \mathrm{O}\right)$, which could be due to the increase in the pressure drop caused by increasing amount of the $\mathrm{H}_{2} \mathrm{O}$ molecules condensed at around the hetero interface. This affection was more pronounced in the case using the $\mathrm{H}_{2}-\mathrm{N}_{2}$ (2:1) mixed feed gas, $i$. $e$. when the driving force for $\mathrm{N}_{2}$ gas permeation was reduced by decreasing the partial pressure difference between the gas feed side and permeate side of the membrane under the saturated water vapor partial pressure at $50^{\circ} \mathrm{C}$ (Fig. $5(\mathrm{c})$ and (d)). On the other hand, at p/p $\mathrm{p}_{0}\left(\mathrm{H}_{2} \mathrm{O}\right)>$ 0.1 , the water vapor exhibited a stable permeation with a relatively high permeance of approximately $3 . \sigma_{10}^{-7}\left[\mathrm{~mol} \mathrm{~m}^{-2} \mathrm{~s}^{-1} \mathrm{~Pa}^{-1}\right]$ at $50{ }^{\circ} \mathrm{C}$ (Fig. 5(a)). The observed water vapor permeation was thought to be governed by the surface diffusion/capillary condensation along with the extremely hydrophilic $\mathrm{\gamma}-\mathrm{Al}_{2} \mathrm{O}_{3}$ mesopore wall.

\section{Summary}

In the present study, super hydrophobicity of PCSs was characterized by measuring water vapor adsorption-desorption isotherms at $25^{\circ} \mathrm{C}$. 
Then, the PCS membrane with a thickness of about $50 \mathrm{~nm}$ was successfully formed over a mesoporous $\gamma-\mathrm{Al}_{2} \mathrm{O}_{3}$ layer placed on an outer surface of a macroporous $\alpha-\mathrm{Al}_{2} \mathrm{O}_{3}$ tubular support. Under dry and wet condition, gas permeances through the supported PCS membranes were assessed and discussed to clarify their possible permeation mechanisms. The results can be summarized as follows:

(1) Water vapor adsorption-desorption isotherms measurements revealed that the amount of water adsorption under the saturated water vapor partial pressure at $25{ }^{\circ} \mathrm{C}$ of the PCSs was below 4 $\mathrm{cm}^{3}(\mathrm{STP}) \mathrm{g}^{-1}$, which showed significantly high hydrophobicity.

(2) Under dry condition at $50{ }^{\circ} \mathrm{C}$, the supported membrane synthesized using PCS having Mw of 4042 (PCS(A)) exhibited the best membrane performance: the $\mathrm{H}_{2}$ permeance of $1 . \mathrm{k} 10^{-6} \mathrm{~mol}^{-1}$ $\mathrm{m}^{-2} \mathrm{~s}^{-1} \mathrm{~Pa}^{-1}$ and $\alpha\left(\mathrm{H}_{2} / \mathrm{N}_{2}\right)$ of 12.6 together with unique $\alpha\left(\mathrm{H}_{2} /\right.$ $\mathrm{He})$ of 1.4 .

(3) Even under saturated water vapor partial pressure at $50{ }^{\circ} \mathrm{C}$, the PCS(A) kept a relatively high $\mathrm{H}_{2}$ permeance of $7.7 \times 10^{-8} \mathrm{~mol}^{-1}$ $\mathrm{m}^{-2} \mathrm{~s}^{-1} \mathrm{~Pa}^{-1}$ with improved $\mathrm{H}_{2} / \mathrm{N}_{2}$ selectivity of 26 .

(4) The dominant mechanism for $\mathrm{He}$ and $\mathrm{H}_{2}$ permeations through the PCS top-layer was suggested as solid state diffusion. The activation energy for the $\mathrm{H}_{2}$ permeation was estimated as $5.8 \mathrm{~kJ} \mathrm{~mol}^{-1}$ and was found to be slightly lower than that for the He permeation $\left(5.9 \mathrm{~kJ} \mathrm{~mol}^{-1}\right)$.

(5) The activation energy for $\mathrm{N}_{2}$ permeation through the supported PCS membrane was estimated by using the mGT model as $13.6 \mathrm{~kJ}$ $\mathrm{mol}^{-1}$. This value was compatible with that obtained by the conventional Arrhenius plot $\left(11.9 \mathrm{~kJ} \mathrm{~mol}^{-1}\right)$.

(6) The enhanced $\mathrm{H}_{2}$-permeselectivity observed under the highhumidity conditions at $50{ }^{\circ} \mathrm{C}$ was explained by the synergistic effect of the preferential $\mathrm{H}_{2}$ permeation through the dense PCS top-layer networkand blockage of $\mathrm{N}_{2}$ permeation pathway by the permeate $\mathrm{H}_{2} \mathrm{O}$-induced plugging. As a result, when the $\mathrm{H}_{2}-\mathrm{N}_{2}$ (2:1) mixed feed gas was used for measuring gas permeances under saturated humidity at $50{ }^{\circ} \mathrm{C}$, the $\mathrm{N}_{2}$ permeance was below the limit of detection, which showed great potential of PCSs to develop high-performance membranes for hydrogen recovery from the syngas produced by the novel solar hydrogen production systems.

\section{Funding}

This work was in part supported by "Research Project for Future Development: Artificial Photosynthetic Chemical Process (ARPChem)" (METI/NEDO, Japan: 2012-2022). Dr. Samuel Bernard and Prof. Yuji Iwamoto would like to thank CNRS who financially supported present work via the International Research Project (IRP) 'Ceramics materials for societal challenges'.

\section{References}

[1] K. Maeda, K. Domen, New non-oxide photocatalysts designed for overall wate splitting under visible light, J. Phys. Chem. C 111 (2007) 7851-7861, https://doi. org/10.1021/jp070911w.

[2] Q. Wang, T. Hisatomi, Q. Jia, H. Tokudome, M. Zhong, C. Wang, Z. Pan, T. Takata, M. Nakabayashi, N. Shibata, Y. Li, I.D. Sharp, A. Kudo, T. Yamada, K. Domen, Scalable water splitting on particulate photocatalyst sheets with a solar-tohydrogen energy conversion efficiency exceeding 1\%, Nat. Mater. 15 (2016) 611-615, https://doi.org/10.1038/nmat4589.

[3] Y. Goto, T. Hisatomi, Q. Wang, T. Higashi, K. Ishikiriyama, T. Maeda, Y. Sakata S. Okunaka, H. Tokudome, M. Katayama, S. Akiyama, H. Nishiyama, Y. Inoue, T. Takewaki, T. Setoyama, T. Minegishi, T. Takata, T. Yamada, K. Domen, A particulate photocatalyst water-splitting panel for large-scale solar hydrogen generation, Joule 2(2018)509-520, https://doi.org/10.1016/j.joule.2017.12.009.

[4] S. Yagyu, H. Matsui, T. Matsuda, H. Yasumoto, Studies of explosive characteristics of hydrogen (1st report), Minist. Labour, Res. Inst. Ind. Saf. (1969) .

[5] K. Tanaka, Y. Sakata, Present and future prospects of hydrogen production process constructed by the combination of photocatalytic $\mathrm{H}_{2} \mathrm{O}$ splitting and membrane separation process, Membrane 36 (2011) 113-121, https://doi.org/10.5360/ membrane.36.113.

[6] H. Yin, A.C.K. Yip, A review on the production and purification of biomass-derived hydrogen using emerging membrane technologies, Catalysts 7 (2017) 297, https:// doi.org/10.3390/catal7100297.

[7] S.T. Oyama, S.M. Stagg-Williams, Inorganic, Polymeric and Composite Membranes: Structure, Function and Other Correlations, Elsevier, Amsterdam, 2011.

[8] T. Yamaguchi, A. Takagaki, T. Sugawara, R. Kikuchi, S.T. Oyama, Supported fluorocarbon liquid membranes for hydrogen/oxygen separation, J. Memb. Sci. 520 (2016) 272-280, https://doi.org/10.1016/j.memsci.2016.07.010.

[9] Y. Iwamoto, Precursors-derived ceramic membranes for high-temperature separation of hydrogen, J. Ceram. Soc. Japan 115 (2007) 947-954, https://doi. org/10.2109/jcersj2.115.947.

[10] A. Burneau, J. Lepage, G. Maurice, Porous silica-water interactions. I. Structural and dimensional changes induced by water adsorption, J. Non. Cryst. Solids 217 (1997) 1-10, https://doi.org/10.1016/S0022-3093(97)00113-0.

[11] T. Tsuru, T. Hino, T. Yoshioka, M. Asaeda, Permporometry characterization of microporous ceramic membranes, J. Memb. Sci. 186 (2001) 257-265, https://doi. org/10.1016/S0376-7388(00)00692-X.

[12] J. Wen, G.L. Wilkes, Organic/inorganic hybrid network materials by the sol-gel approach, Chem. Mater. 8 (1996) 1667-1681, https://doi.org/10.1021/ cm9601143.

[13] U. Díaz, A. Corma, Organic-inorganic hybrid materials: multi-functional solids for multi-step reaction processes, Chem. - A Eur. J. 24 (2018) 3944-3958, https://doi. org/10.1002/chem.201704185.

[14] P. Judeinstein, C. Sanchez, Hybrid organic-inorganic materials: a land of multidisciplinarity, J. Mater. Chem. 6 (1996) 511-525, https://doi.org/10.1039/ JM9960600511.

[15] C. Sanchez, B. Julián, P. Belleville, M. Popall, Applications of hybrid organicinorganic nanocomposites, J. Mater. Chem. 15 (2005) 3559-3592, https://doi.org/ 10.1039/b509097k.

[16] S. Yajima, J. Hayashi, M. Omori, Continuous silicon carbide fiber of high tensile strength, Chem. Lett. 4 (1975) 931-934, https://doi.org/10.1246/cl.1975.931.

[17] S. Yajima, K. Okamura, J. Hayashi, M. Omori, Synthesis of continuous SiC fibers with high tensile strength, J. Am. Ceram. Soc. 59 (1976) 324-327, https://doi.org/ 10.1111/j.1151-2916.1976.tb10975.x.

[18] F. Sandra, A. Ballestero, V.L. Nguyen, M.N. Tsampas, P. Vernoux, C. Balan, Y. Iwamoto, U.B. Demirci, P. Miele, S. Bernard, Silicon carbide-based membranes with high soot particle filtration efficiency, durability and catalytic activity for $\mathrm{CO} /$ HC oxidation and soot combustion, J. Memb. Sci. 501 (2016) 79-92, https://doi org/10.1016/j.memsci.2015.12.015.

[19] D. Hotza, M. Di Luccio, M. Wilhelm, Y. Iwamoto, S. Bernard, J.C. Diniz da Costa, Silicon carbide filters and porous membranes: a review of processing, properties, performance and application, J. Memb. Sci. 610 (2020), 118193, https://doi.org/ 10.1016/j.memsci.2020.118193.

[20] L.V. Interrante, Q. Shen, Polycarbosilanes, in: R.G. Jones, W. Ando, J. Chojnowsk (Eds.), Silicon-Containing Polym., Kluwer Academic Publisher, Netherlands, 2000 pp. 247-321. ISBN: 9780412831102.

[21] K. Matsumoto, Polycarbosilanes, in: H.F. Mark (Ed.), Encycl. Polym. Sci. Technol., John Wiley \& Sons, New York, 2003, pp. 426-438. ISBN: 978-1-118-63389-2.

[22] Y. Sawai, Y. Iwamoto, S. Okuzaki, Y. Yasutomi, K. Kikuta, S. Hirano, Synthesis of silicon carbide ceramics using chemically modified polycarbosilanes as a compaction binder, J. Am. Ceram. Soc. 82 (1999) 2121-2125, https://doi.org/ 10.1111/j.1151-2916.1999.tb02051.x.

[23] M. Kubo, M. Kojima, R. Mano, Y. Daiko, S. Honda, Y. Iwamoto, A hydrostable mesoporous $\mathrm{Y}^{-} \mathrm{Al}_{2} \mathrm{O}_{3}$ membrane modified with $\mathrm{Si}-\mathrm{C}-\mathrm{H}$ organic-inorganic hybrid derived from polycarbosilane, J. Memb. Sci. 598 (2020), 117799, https://doi.org/ derived from polycarbosilane, J.M
$10.1016 / \mathrm{j}$. memsci.2019.117799.

[24] Currently, polycarbosilanes ("Nipusi®”) are available from Artkagaku Co. Ltd., http://www.artkagaku.co.jp/contact/index.html. 
[25] M.H. Zahir, K. Sato, Y. Iwamoto, Development of hydrothermally stable sol-gel derived $\mathrm{La}_{2} \mathrm{O}_{3}$-doped $\mathrm{Ga}_{2} \mathrm{O}_{3}-\mathrm{Al}_{2} \mathrm{O}_{3}$ composite mesoporous membrane, J. Memb. Sci. 247 (2005) 95-101, https://doi.org/10.1016/j.memsci.2004.09.011.

[26] M.H. Zahir, K. Sato, H. Mori, Y. Iwamoto, M. Nomura, S.I. Nakao, Preparation and properties of hydrothermally stable $\gamma$-alumina-based composite mesoporous membranes, J. Am. Ceram. Soc. 89 (2006) 2874-2880, https://doi.org/10.1111/ j.1551-2916.2006.01165.x.

[27] D.W. Breck, Zeolite Molecular Sieves: Structure, Chemistry, and Use, John Wiley \& Sons, New York, 1974 https://doi.org/10.1093/chromsci/13.4.18A-c.

[28] K.S.W. Sing, D.H. Everett, R.A.W. Haul, L. Moscou, R.A. Pierotti, J. Rouquerol, T. Siemienieska, Reporting physisorption data for gas/solid systems with special reference to the determination of surface area and porosity, Pure Appl. Chem. 57 (1985) 603-619. ISBN: 978-1-4020-2303-3.

[29] S. Lowell, J.E. Shields, M.A. Thomas, M. Thommes, Characterization of Porous Solids and Powders, Springer, Netherlands, 2004.

[30] M.N. Mohd Sokri, T. Onishi, Y. Daiko, S. Honda, Y. Iwamoto, Hydrophobicity of amorphous silica-based inorganic-organic hybrid materials derived from perhydropolysilazane chemically modified with alcohols, Microporous Mesoporous Mater. 215 (2015) 183-190, https://doi.org/10.1016/j.micromeso.2015.05.039.

[31] Z. Mouline, K. Asai, Y. Daiko, S. Honda, S. Bernard, Y. Iwamoto, Aminefunctionalized polycarbosilane hybrids for $\mathrm{CO}_{2}$-selective membranes, J. Eur. Ceram. Soc. 37 (2017) 5213-5221, https://doi.org/10.1016/j. jeurceramsoc.2017.04.008

[32] X. Ren, T. Tsuru, Organosilica-based membranes in gas and liquid-phase separation, Membranes 9 (2019) 107, https://doi.10.3390/membranes9090107.

[33] T. Yamada, K. Domen, Development of sunlight driven water splitting devices towards future artificial photosynthetic industry, ChemEngineering 2 (2018) 36, https://doi.org/10.3390/chemengineering2030036.

[34] R.M. de Vos, H. Verweij, High-selectivity, high-flux silica membranes for gas separation, Science 279 (1998) 1710-1711, https://doi.org/10.1126/ science. 279.5357.1710.

[35] Y. Iwamoto, K. Sato, T. Kato, T. Inada, Y. Kubo, A hydrogen-permselective amorphous silica membrane derived from polysilazane, J. Eur. Ceram. Soc. 25 (2005) 257-264, https://doi.org/10.1016/j.jeurceramsoc.2004.08.007.

[36] A.K. Prabhu, S.T. Oyama, Highly hydrogen selective ceramic membranes: application to the transformation of greenhouse gases, J. Memb. Sci. 176 (2000) 233-248, https://doi.org/10.1016/S0376-7388(00)00448-8.

[37] T. Yoshioka, M. Kanezashi, T. Tsuru, Micropore size estimation on gas separation membranes: a study in experimental and molecular dynamics, AIChE J. 59 (2013) 2179-2194, https://doi.org/10.1002/aic.13966.

[38] M. Kanezashi, T. Tsuru, Design of amorphous silica network structure for molecular sieving membranes and evaluation of pore size by normalized Knudsen- based permeance (NKP), Zeolite 35 (2018) 13-22, https://doi.org/10.20731/ zeoraito.35.1.13.

[39] S.T. Oyama, D. Lee, P. Hacarlioglu, R.F. Saraf, Theory of hydrogen permeability in nonporous silica membranes, J. Memb. Sci. 244 (2004) 45-53, https://doi.org/ 10.1016/j.memsci.2004.06.046.

[40] S.T. Oyama, M. Yamada, T. Sugawara, A. Takagaki, R. Kikuchi, Review on mechanisms of gas permeation through inorganic membranes, J. Japan Pet. Inst. 54 (2011) 298-309, https://doi.org/10.1627/jpi.54.298.

[41] Y. Gu, S.T. Oyama, High molecular permeance in a poreless ceramic membrane, Adv. Mater. 19 (2007) 1636-1640, https://doi.org/10.1002/adma.200602637.

[42] S.J. Ahn, G.N. Yun, A. Takagaki, R. Kikuchi, S.T. Oyama, Synthesis and characterization of hydrogen selective silica membranes prepared by chemical vapor deposition of vinyltriethoxysilane, J. Memb. Sci. 550 (2018) 1-8, https:// doi.org/10.1016/j.memsci.2017.12.038.

[43] P.L. Studt, J.F. Shackelford, R.M. Fulrath, Solubility of gasesin glass-a monatomic model, J. Appl. Phys. 41 (1970) 2777-2780, https://doi.org/10.1063/1.1659314.

[44] J.S. Masaryk, R.M. Fulrath, Diffusivity of helium in fused silica, J. Chem. Phys. 59 (1973) 1198-1202, https://doi.org/10.1063/1.1680168.

[45] R.M. Prasad, Y. Jüttke, H. Richter, I. Voigt, R. Riedel, A. Gurlo, Mechanism of gas separation through amorphous silicon oxycarbidemembranes, Adv. Eng. Mater. 18 (2016) 721-727, https://doi.org/10.1002/adem.201500380.

[46] D. Lee, L. Zhang, S.T. Oyama, S. Niu, R.F. Saraf, Synthesis, characterization, and gas permeation properties of a hydrogen permeable silica membrane supported on porous alumina, J. Memb. Sci. 231 (2004) 117-126, https://doi.org/10.1016/j. memsci.2003.10.044.

[47] Y. Mise, S.J. Ahn, A. Takagaki, R. Kikuchi, S.T. Oyama, Fabrication and evaluation of trimethylmethoxysilane (TMMOS)-derived membranes for gas separation, Membranes 9 (2019) 123, https://doi.org/10.3390/membranes9100123.

[48] L.-L. Lee, D.-S. Tsai, A hydrogen-permselective silicon oxycarbide membrane derived from polydimethylsilane, J. Am. Ceram. Soc. 82 (1999) 2796-2800, https://doi.org/10.1111/j.1151-2916.1999.tb02158.x.

[49] T. Yoshioka, E. Nakanishi, T. Tsuru, M. Asaeda, Experimental studies of gas permeation through microporous silica membranes, AIChE J. 47 (2001) 2052-2063, https://doi.org/10.1002/aic.690470916.

[50] A.B. Shelekhin, A.G. Dixon, Y.H. Ma, Theory of gas diffusion and permeation in inorganic molecular-sieve membranes, AIChE J. 41 (1995) 58-67, https://doi.org/ 10.1002/aic.690410107.

[51] R.S.A. de Lange, K. Keizer, A.J. Burggraaf, Analysis and theory of gas transport in microporous sol-gel derived ceramic membranes, J. Memb. Sci. 104 (1995) 81-100, https://doi.org/10.1016/0376-7388(95)00014-4.

[52] A.J. Burggraaf, Single gas permeation of thin zeolite (MFI) membranes: theory and analysis of experimental observations, J. Memb. Sci. 155 (1999) 45-65, https:// doi.org/10.1016/S0376-7388(98)00295-6. 